\title{
Presidential Authority to Revoke or Reduce National Monument Designations
}

\author{
John $\mathbf{Y o o}^{\dagger} \&$ Todd Gaziano ${ }^{\ddagger}$
}

The Antiquities Act of 1906 was passed in order to protect threatened historic ruins, structures and landmarks, and accordingly, it grants the President the power to designate such features as national monuments. Despite this goal, several Presidents have used this authority to unilaterally withdraw hundreds of thousands of acres of federal land from public use.

Moreover, many scholars now claim that while the Act gives a President the power to designate a national monument, it does not allow for significant presidential reductions or revocation. They argue that the absence of an explicit grant of revocation power in the Act as well as the language of contemporaneous statutes mean that once a monument is created by a President, only Congress can alter or revoke it.

Our analysis shows that a general discretionary revocation power does exist for the President. We argue that under traditional principles of constitutional, legislative, and administrative law, the authority to execute a discretionary power includes the authority to reverse it. Arguments that treat national monuments as a special case rely on a 1938 opinion by U.S. Attorney General Homer Cummings, which concluded that the Act did not grant the power of revocation. We argue that this opinion is poorly reasoned; misconstrued a prior opinion, which came to the opposite result; and is inconsistent with constitutional, statutory, and case law governing the President's exercise of analogous grants of power.

Introduction

I. The Modern Administrative State and the Antiquities Act in Context......622

A. Historical and Legal Background of the Antiquities Act..

B. Academic Literature.

II. A General Discretionary Power to Revoke Prior Designations.

A. The Cummings Opinion.

$\dagger$ John Yoo is Emanuel S. Heller Professor of Law at the University of California, Berkeley and a Visiting Scholar at the American Enterprise Institute.

$\ddagger \quad$ Todd Gaziano is Director of the Pacific Legal Foundation's Center for the Separation of Powers and its Senior Fellow in Constitutional Law. The authors thank Jonathan Wood for his substantial contribution on the marine monument discussion and other insights on the broader topic, and Peter De Golia and Leah Hamlin for their excellent research assistance with this Article. 
B. The General Power of Reversal Inherent in American Law.

C. Procedures to Create, Modify, or Revoke National Monuments....647

III. A Limited Power to Revoke Certain National Monuments or Declare Others Invalid. .650

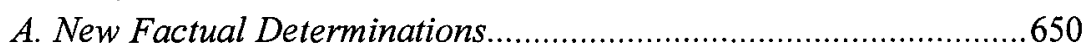

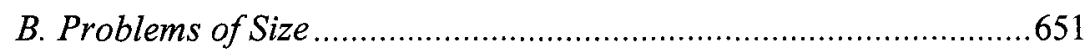

C. Special Questions Regarding Marine Monument Designations ....656

IV. The Power to Reduce the Scope of a Reservation in a Monument

Designation

Conclusion.

\section{Introduction}

Few should doubt that elections have consequences, especially in the area of environmental regulation. In the waning days of his term in office, President Barack Obama announced the withdrawal of millions of acres of Atlantic and Arctic territory from petroleum development under the Outer Continental Shelf Lands Act. ${ }^{1}$ President Obama continued his orders on December 28, 2016, proclaiming 1.35 million acres in Utah and 300,000 acres in Nevada to be new national monuments under the Antiquities Act. ${ }^{2}$ Attempting to insulate these changes from the actions of future administrations, White House aides contended that both withdrawals were "permanent" because there was no express authority to reverse them. ${ }^{3}$

In this Article, we argue that the claim of executive permanence gets constitutional principles and legal presumptions exactly backwards. President Donald Trump has begun to review and significantly modify recent national monuments, including those proclaimed by President Obama in 2016. What will be of lasting significance is the outcome of the legal dispute over whether federal land withdrawals and monument designations are unique among executive actions in their immunity from subsequent presidential alteration or reversal. That resolution has profound implications, not only for federal land policy, but for the operation of the administrative state generally.

On April 26, 2017, President Trump ordered administration officials to study certain national monument designations issued during the previous twenty-

1. See Memorandum on Withdrawal of Certain Portions of the United States Arctic Outer Continental Shelf from Mineral Leasing, 2016 DAILY COMP. PRES. DOC. DOC. 3 (Dec. 20, 2016); Memorandum on Withdrawal of Certain Areas off the Atlantic Coast on the Outer Continental Shelf from Mineral Leasing, 2016 DAILY COMP. PRES. DOC. 4 (Dec. 20, 2016).

2. Antiquities Act of 1906, Pub. L. 59-209, 34 Stat. 225 (codified at 54 U.S.C. $\S \S$ 320301-03 (2012)); Proclamation 9558 Establishment of the Bears Ears National Monument 2016 DAILY COMP. PRES. DOC. 2 (Dec. 28, 2016); Proclamation 9559 - Establishment of the Gold Butte National Monument 2016 DAILY COMP. PRES. DOC. 3 (Dec. 28, 2016).

3. Juliet Eilperin \& Brady Dennis, Monuments to Obama's Legacy?, WASH. POST, Dec. 29,2016 , at A2, WLNR 39726650 . 
one years and to make recommendations on reversing the decisions of past Presidents or narrowing their scope. ${ }^{4}$ On June 10, 2017, Interior Secretary Ryan Zinke issued an interim recommendation to significantly reduce the size of Bears Ears National Monument in Utah, which President Barack Obama designated shortly before leaving office. ${ }^{5}$ In late August, Secretary Zinke issued his final recommendations to the President, reportedly to reduce Bears Ears and three other monuments. ${ }^{6}$

On December 4, 2017, President Trump issued two proclamations reducing the size of Bears Ears and Grand Staircase-Escalante National Monuments, both in Utah, by approximately eighty-five and forty-seven percent respectively. ${ }^{7}$ Presidential action on other national monuments may follow, but several suits have already been filed challenging the President's monument reductions to Bears Ears and Grand Staircase-Escalante, ${ }^{8}$ and one lawsuit is pending to require the revocation of one marine monument that is 130 to 200 miles from the coast of New England. ${ }^{9}$ This Article argues that the executive branch has the legal authority to revoke or significantly reduce existing national monuments. ${ }^{10}$

The Antiquities Act of 1906 grants the President the power to designate national monuments in order to protect historic landmarks and structures. Pursuant to this power, a President has the corresponding power to revoke prior

4. Exec. Order 13,792, 82 Fed. Reg. 20,429 (April 26, 2017) (applying to all monuments greater than 100,000 acres that were created during the previous twenty-one years, plus any that the Secretary of Interior determined had been designated without adequate public input). Secretary Zinke subsequently identified twenty-two national monuments on land that fit the review criteria, only one of which (Katahdin Woods and Waters National Monument) covered less than 100,000 acres. Pursuant to Exec. Order 13,795, 82 Fed. Reg. 20,816 (April 28, 2017), the Secretary of Commerce, with in put from the Secretary of. Interior, was tasked with reviewing and making similar recommendations with regard to five national monument designations on the high seas in the Pacific and Atlantic Oceans from 2006-2016, the largest of which is almost ninety million acres.

5. Memorandum from Ryan K. Zinke, Sec'y of Interior, on Interim Report Pursuant to Executive Order 13,792 to the President (June 10, 2017), http://www.scribd.com/document/351066813 /nterim-Report-EO-13792 [http://perma.cc/5YYU-BFXN].

6. See Julie Turkewitz \& Lisa Friedman, Interior Secretary Proposes Shrinking Four National Monuments, N.Y. TLMES (Aug. 24, 2017), http://www.nytimes.com/2017/08/24/us/bears-earsutah-monument.html [http://perma.cc/3YAE-R34K] (reporting that Secretary Zinke's recommendations were never officially released, but supposed copies of the recommendations were published by the press); cf. N.Y. Times v. U.S. Dep't of Interior, No. 1:17-cv-9883 (S.D.N.Y. filed Dec. 18, 2017) (FOIA request for records relating to the reduction)

7. Proclamation No. 9681, 82 Fed. Reg. 58,081 (Dec. 4, 2017); Proclamation No. 9682, Fed. Reg. 58,089 (Dec. 4, 2017).

8. So far, three suits have been filed to overturn Trump's reduction of Bears Ears, namely Hopi Tribe v. Trump, No. 17 -cv-2590 (D.D.C. filed Dec. 4, 2017), NRDC v. Trump, No. 17-cv2606 (D.D.C. filed Dec. 7, 2017), and Utah Dine Bikeyah v. Trump, No. 17-cv-2605 (D.D.C. filed Dec. $6,2017)$. The two that challenge Trump's reduction of Grand Staircase-Escalante are The Wilderness Society v. Trump, No. 17-cv-2587 (D.D.C. filed Dec. 4, 2017), and Grand Escalante Partners v. Trump, No. 17-cv-2591 (D.D.C. filed Dec. 7, 2017).

9. See infra note 179 and accompanying text.

10. In addition, one of us helped write comments for the Pacific Legal Foundation recommending such action by the President regarding Bears Ears. See Jeffrey McCoy, Todd Gaziano \& Jonathan Wood, Comment on Review of the Bears Ears National Monument, PAC. LEGAL FouND. (May 25, 2017), http://blog.pacificlegal.org/wp/wp-content/uploads/2017/05/PLF-Comments-on-Bears-EarsMay-25-2017.pdf [http://perma.cc/D725-87WN]. 
national monument designations. Although there is no controlling judicial authority on this question, the Act's text and historical practice confirm that the Chief Executive can significantly reduce the size of prior designations that cover vast areas of land and ocean habitat, and pursuant to settled law that applies to every other grant of power, the President retains the authority to revoke any existing monument.

Many scholars, however, take a different view. In a recent essay, for example, prominent U.S. environmental law scholars argued that a President cannot reverse or narrow the designation of an earlier national monument. ${ }^{11}$ More than 120 law professors recently signed a letter making the same argument. $^{12}$ Their work relies on a 1938 opinion by U.S. Attorney General Homer Cummings, which concluded that the statutory power granted to the President to create national monuments does not include the power of revocation. ${ }^{13}$ The opinion has been cited a few times in government documents, including by the Solicitor of the Interior Department in 1947 (although for a different proposition) and in legal commentary, but the courts have never relied on it. We think this opinion (and the subsequent work which relied upon it) is poorly reasoned; misconstrues a prior opinion, which actually came to the opposite result; and is inconsistent with constitutional, statutory, and case law governing the President's exercise of analogous grants of power.

What is striking about the underlying claim-that the President lacks authority to undo a previous President's monument designation (especially in the absence of an express bar on such subsequent action) - is that there is no instance in American law in which a court has held that a grant of authority does not include the power of the relevant office holder to revoke prior uses of that power. Extraordinary authority is required for the extraordinary claim that the Antiquities Act is unique among all grants of power such that silence as to revocation results in the opposite conclusion of every other case.

In contrast, our analysis explains why a general discretionary revocation power under the Antiquities Act must exist. That is the best reading of the Act's text; history, and purposes. That conclusion is also supported by a strong presumption under constitutional, statutory, and administrative law that every grant of power includes the power of revocation. ${ }^{14}$ Finally, it would be

11. See Mark Squillace et al,, Presidents Lack the Authority To Abolish or Diminish National Monuments, 103 VA. L. REV. ONLINE 55 (2017).

12. Letter from Law Professors to Sec'ys Zinke and Ross (July 6, 2017), http://legalplanet.org/wp-content/uploads/2017/07/national-monuments-comment-letter-from-law-professors_asfiled.pdf [http://perma.cc/62U2-NNWM].

13. See Proposed Abolishment of Castle Pinckney National Monument, 39 Op. Att'y Gen. 185 (1938) [hereinafter Cummings Opinion].

14. One minor but intuitive proof of the background principle to national monument authority is that it would make little sense for Congress to go through the legislative trouble to turn a national monument into a national park, and the environmental community would not push so hard for such conversion, except that national park designations under law protect the land more permanently than national monument designations alone. 
constitutionally questionable, at least in most instances, for Congress to attempt to grant Presidents a power by statute that a subsequent President must enforce but could not rescind or modify. Thus, the courts should require a clear statement from Congress that it was attempting to prevent a later President from revoking a national monument designation. The Antiquities Act contains no such explicit bar on revoking earlier proclamations.

Apart from a power to revoke monuments that were lawfully designated, the President has the constitutional power to declare invalid prior monuments if they were illegal from their inception. There is no reason why a President should give effect to an illegal act of his predecessor pending a judicial ruling. The President may also have a duty to revoke monument designations based on earlier factual error or changed circumstances, even if he does not possess a general discretionary revocation power.

Almost all commentators concede that some boundary adjustments can be made to monument designations, and many have been made over the years. In 2005, the Supreme Court implicitly recognized that such adjustments can be made. ${ }^{15}$ The only serious question is over their scope. No court has ruled on this question. Some commentators claim, inaccurately, that this lack of case law is the result of no President attempting to significantly reduce the size of an existing monument. In the Antiquities Act's early years alone, the size of some monuments was reduced by half or more. One was reduced by almost ninety percent. $^{16}$

Regardless of past practice, arguments that limit the President's authority to significantly reduce prior designations are largely conclusory-and based on the erroneous premise that the President lacks authority to revoke monumentsor driven by a selective reading of the Act's purpose rather than its text. We believe that a President's discretion to change monument boundaries is broad, but even if that is not so, his power to significantly change monument boundaries is at its height if the original designation was unreasonably large under the facts as they existed then or based on changed circumstances.

Part I of this Article describes the factual, legal, and historical background for the current controversy over national monuments and the scope of the Antiquities Act. We also critique the views of scholars who believe only Congress can overturn the designation of a national monument. Part II sets out the affirmative case for a presidential power to reverse previous designations of national monuments under the Antiquities Act. We argue that under traditional principles of constitutional, legislative, and administrative law, the authority to execute a discretionary power includes the authority to reverse it. No President (nor any Congress or Supreme Court) can permanently bind subsequent Presidents in their exercise of the executive power. Part III explains that even if one were to disagree with Part II's broad argument, the Antiquities Act by its

15. See Alaska v. United States, 545 U.S. 75 (2005).

16. See infra notes 198-201 and accompanying text. 
own terms contains an ongoing authority to reverse a monument designation. Part IV shows that even if the President does not enjoy a constitutional or statutory power to repeal a monument, he or she still has the delegated authority to reduce and alter the size of a monument to ensure that it is the smallest size necessary. Rather than broadly declaring millions of acres off limits, Presidents can make their national monuments enduring by seeking a more consensual process involving Congress, state officials, and local stakeholders.

\section{The Modern Administrative State and the Antiquities Act in Context}

The congressional grant of power to the President in the Antiquities Act of 1906 was an early example of what would give rise to the modern administrative state. Although Congress granted the President power in the Antiquities Act to increase protections for certain federal lands without congressional approval, it is a weakly protective statute compared to environmental, labor, financial and - other domestic legislation enacted between 1945 and the present, especially after 1960.

The Antiquities Act empowers the President to take certain actions as he sees fit, but as explained further below, he has absolutely no duty to take any protective action, either collectively or at any particular site. No one can require the President to make any determination or create a single new national monument. In contrast, the environmental statutes of the last forty-five years create numerous mandatory duties to protect the air, water, and other sensitive areas. Suits can and are brought to enforce these affirmative mandates, and they include actions under the relevant statute and the Administrative Procedure Act for "action unlawfully withheld or unreasonably delayed." 17 Based on these statutory imperatives, we can reasonably conclude that Congress considered the protective purpose of each of these modern statutes to be more important than that of the Antiquities Act.

Besides the forest of environmental laws, hundreds of other laws mandate protections for worker safety, consumer safety, civil rights, securities trading, food and pharmaceutical safety, consumer financial transactions, and a host of other concerns. These laws authorize, and often require, the issuance of regulations to further the statute's protective purposes. And as we discuss in Part II, it is well established that a new President may significantly modify or revoke such regulations or other actions. ${ }^{18}$ It is in this context that we examine the

17. See 5 U.S.C. $\S 706(1)(2018)$ (authorizing judicial review of actions to "compel agency action unlawfully withheld or unreasonably delayed").

18. See Nat'l Cable \& Telecomm. Ass'n v. Brand X Internet Servs., 545 U.S. 967 (2005). Litigation over the content of regulatory or other changes is possible, but there is no legal ground to assert that the incumbent President is foreclosed from all meaningful change. Indeed, if the statute is a weakly protective one and does not require a particular finding or action in the first instance, as is true with the Antiquities Act, the President's range of substantive options are generally extremely broad. He must follow the applicable administrative procedures, which often require him to pursue notice and 
extraordinary claim that the Antiquities Act, by its silence, is the one "protective" statute in the U.S. Code that prohibits an incumbent President from modifying an earlier President's actions.

\section{A. Historical and Legal Background of the Antiquities Act}

In 1872, Yellowstone National Park was designated the United States' first national park, withdrawing two million acres of federal land for preservation and public enjoyment. ${ }^{19}$ Since the 1890 s, however, Congress and the Executive frequently argued about the proper authority to withdraw other federal lands from general use. Different laws were used to create or authorize national forests and other national preservation designations. It was not until 1916 that Congress created the Act to Establish the National Park Service to help manage and regularize the creation of national parks, but even now, each national park must be created by an Act of Congress. ${ }^{20}$

Almost one quarter of the units that comprise the National Park System can trace their origins to the Antiquities Act of $1906,{ }^{21}$ but the creation of large scenic "parks" was not the Antiquities Act's purpose and is a violation of the spirit if not the letter of the Act. The original motive for the Antiquities Act was to protect ancient and prehistoric American Indian archeological sites on federal lands in the southwest from looting. The Antiquities Act was passed during the same month (June 1906) as the act creating Mesa Verde National Park, and the problems that arose in protecting the Mesa Verde ruins inform the Antiquities Act's central focus. ${ }^{22}$

In a report to the Secretary of the Interior, Smithsonian Institution archeologist Jesse Walter Fewkes described vandalism at Mesa Verde's Cliff Palace:

Parties of "curio seekers" camped in the ruin for several winters, and it is reported that many hundred specimens therefrom have been carried down the mesa and sold to private individuals. Some of these objects are now in museums, but many are forever lost to science. In order to secure this valuable archaeological material, walls were broken down ... often simply to let light into the darker rooms; floors were invariably opened and buried kivas mutilated. To facilitate this work and get rid of the debris, great openings were broken through the fine walls which form

comment rulemaking procedures and explain his change of position, but that is not a serious substantive limitation.

19. National Park System Timeline, NAT'L PARK SERVICE (2017), http://www.nps.gov /parkhistory/hisnps/npshistory/timeline_annotated.htm [http://perma.cc/LDW8-T5PC].

20. National Park Service Organic Act, 54 U.S.C. $\S \S 100101($ a), 100301 et seq. (2018).

21. National Park System Timeline, supra note 19.

22. It is relevant to later arguments over the scope of the Antiquities Act that Congress enacted a statutorily fixed Mesa Verde National Park by separate statute - and did not leave that to the Executive to do so. Among other things, this is further evidence that Congress considered the authority in the Antiquities Act to protect archeological sites from looting as distinct from creating a national park from lands that surround such archeological sites or historical landmarks. 
the front of the ruin. Beams were used for firewood to so great an extent that not a single roof now remains. This work of destruction, added to that resulting from erosion due to torrents of rain, left Cliff Palace in a sad condition. ${ }^{23}$

The Act's text confirms that its primary purpose was to preserve man made artifacts. ${ }^{24}$ Section 1 of the original act made it a crime to "appropriate, excavate, injure, or destroy any historic or prehistoric ruin or monument, or object of antiquity" on federal land without permission. ${ }^{25}$ Section 3 provided for permits for the examination of "ruins, the excavation of archeological sites, and the gathering of objects of antiquity upon" federal land. ${ }^{26}$ Section 4 provided the authority to the relevant department secretaries who managed federal land to issue uniform regulations to carry out the Act's provisions. ${ }^{27}$ Section 2, which allows for the designation of national monuments and the reservation of such federal land as is necessary to protect the "objects" on the land in question (and not scenic views and geological features), also focuses primarily on "historic and prehistoric structures, and other objects of historic or scientific interest."28

The addition of only two words, "historic landmarks," in that sequence in Section 2 (see below) denotes something broader than preserving human artifacts. In prior proposals to protect antiquities, the Department of Interior had sought authority for the President to create scenic monuments and additional national parks, but Congress repeatedly rejected that authority. ${ }^{29}$ Congress was annoyed by large forest designations and guarded its authority over western lands jealously. ${ }^{30}$

As discussed above, Section 2 of the Antiquities Act allows monument designations to protect only small areas around human archeological sites and "historic landmarks." The operative language permits the President:

in his discretion, to declare by public proclamation historic landmarks, historic and prehistoric structures, and other objects of historic or scientific interest that are situated upon the lands owned or controlled by the Government of the United States to be national monuments, and may reserve as a part thereof parcels of land,

23. U.S: DEP'T OF INTERIOR, REPORT TO SECRETARY OF THE INTERIOR FOR FISCAL YEAR ENDED JUNE 30, 1909, at 486-87 (1909).

24. See Antiquities Act of 1906, Pub. L. 59-209, 34 Stat. 225 (codified at 54 U.S.C. $\S \S$ $320301-03(2018))$

25. Id.
26. Id.
$27 . \quad I d$.
28. Id. (emphases added).
29. See H.R. 11021,57 th Cong. $\$ 1(1901)$; Ronald F. Lee, The Antiquities Act, $1900-$ 1906, NAT'L PARK SERV. (Mar. 15, 2016), http://www.nps.gov/archeology/pubs/lee/Lee_CH6.htm [http://perma.cc/8ZUK-W4L6] (discussing Congress's refusal in the period before the Antiquities Act to pass five bills that sought to grant the secretary of the interior broad authority for designating national parks).

30. Id. "The reluctance of the members of the Public Lands Committee, most of them western public lands states, to grant general authority to the Executive Branch to create new national parks is understandable in the light of their past experience with the timber reservations act of $1891 . "$. 
the limits of which in all cases shall be confined to the smallest area compatible with the proper care and management of the objects to be protected. ${ }^{31}$

There are three steps to reserve and protect land under the Antiquities Act. First, the monument must be declared for a protective purpose upon "lands owned or controlled" by the United States. Second, a reservation of certain parcels of land that constitute a "part thereof" may be made, but such parcels of land may not exceed what is necessary to protect the "objects" at issue. Third, the President may specify certain restrictions or other protections that apply to the reserved land, or the relevant department secretary who has responsibility to manage the monument may issue regulations consistent with such protections. ${ }^{32}$

Although the Act's final language covered more than archeological sites, the allowance for small historic landmarks was not meant to include vast scenic or geological parks. As a textual matter, the word "historic" in "historic landmark" must be given some meaning. An historic landmark includes a historic battlefield, an historic home or treaty site, or a historic stop on the Oregon Trail or other well-known marker on a journey. The debates over the Antiquities Act suggest that congressional sponsors were interested in protecting sites made historic by human endeavors and not geologic "history." Moreover, the National Park Service statute of 1916 reaffirmed that national parks could only be created by Congress, and that would have been virtually meaningless if the President could effectively create such parks under the Antiquities Act, albeit without a park designation. ${ }^{33}$

Finally, the Antiquities Act's title, drafting history, and historical context provide powerful additional evidence that the Act was not intended to allow vast scenic or geological monuments. For example, earlier and contemporaneous bills for the same purpose limited monument designation to 320 or 640 acres. $^{34}$ The final bill replaced that with the (now seemingly open-ended) requirement that such monuments "shall be confined to the smallest area compatible with the proper care and management of the objects to be protected." However, that provision was added to provide flexibility for special situations and not to allow

31. Antiquities Act of $1906 \S 2$.

32. Although the National Park Service currently manages most existing national monuments, other units of the Department of Interior (the Bureau of Land Management, and the U.S. Fish and Wildlife Service) manage or co-manage others. The original Act contemplated that the Departments of Agriculture and Defense (then War) might also manage or relinquish land for national monuments and specified that the secretaries of interior, agriculture, and war had authority to jointly issue uniform regulations for managing national monuments. In recent decades, Presidents have given responsibility to the National Oceanic and Atmospheric Administration (in the Department of Commerce) to manage or co-manage marine monuments, and the U.S. Forest Service (in the Department of Agriculture) manages or co-manages certain other recent monuments. See Monuments Protected Under the Antiquities Act, NAT'L PARKS CONSERVATION ASS'N (Jan. 13, 2017), http://www.npca.org/resources/2658-monumentsprotected-under-the-antiquities-act\#sm.00000py0rl7d8qfp5wxkeb7uvkeow [http://perma.cc/UCC6-XE RY].

33. See National Park Service Organic Act, 54 U.S.C. $\$ \S 100101(\mathrm{a}), 100301$ et seq.

34. See Lee, supra note 29. 
a million-acre designation. ${ }^{35}$ Such background also helps illuminate earlier presidential abuses as well as whether such abuses rise to the level of a statutory violation or are just garden-variety political acts that offend individual due process rights and separation of powers principles.

Besides Mesa Verde National Park, only a handful of other national parks existed in 1906. The Grand Canyon, for example, was not a national park in 1906 and was open to mining claims and other federal program leases.

President Theodore Roosevelt initially used his new Antiquities Act authority to protect some relatively small landmarks (e.g., Devils Tower) and Native American ruins (e.g., El Morro and Montezuma Castle), but his abuses were not long in coming. In 1908, he proclaimed the Grand Canyon National Monument, reserving more than 808,000 acres for its protection. Although later Congresses converted some national monuments covering large geological formations into national parks, including the Grand Canyon National Park in 1919, the Congress that enacted the Antiquities Act did not intend monuments of that size to be established by presidential designation. ${ }^{36}$

The disagreements that emerged over the size of national monuments are only marginally relevant to whether a President may significantly reduce or revoke them. The existence of an excessive size claim only cuts in favor of his power to do so. The 50 and 100-plus million acre monuments created since 1980 confirm that Representative Lacey was misled by President Theodore Roosevelt's staff into agreeing to a qualitative size limitation that does not lend itself to easy judicial enforcement. But even assuming the size of monuments is

35. The removal of the 320 or 640 acre limit and substitution of the "smallest area compatible with [protection of the objects in question]" by itself might be ambiguous as to the scope of monuments allowed, but the rest of the Act and its legislative history leave no doubt that vast park-like designations of more than a few thousand acres were not authorized. That President Theodore Roosevelt violated that understanding suggests that his administration was either dishonest in negotiating the final size language or succeeded in fooling congressional sponsors into removing clear size restrictions, but there is little doubt that Congress thought it was providing flexibility for the rare case that a monument might need to be slightly more than 640 acres. More importantly, the scope of monuments allowed under the Act does not affect our main arguments regarding why the President retains authority to revoke or significantly reduce them. Even if we are wrong about the size of monuments allowed in the first instance, that would only heighten the need for Presidents to modify or correct earlier errors or political abuse.

36. A colloquy on the House floor between a House Member and the bill's sponsor, Rep. John F. Lacey, who chaired the Committee on Public Lands, shows that the final change in the bill's language that removed concrete acre limits was not intended to allow especially large designations:

Mr. STEPHENS of Texas. How much land will be taken off the market in the Western States by the passage of the bill?

Mr. LACEY. Not very much. The bill provides that it shall be the smallest area necessary for the care and maintenance of the objects to be preserved.

Mr. STEPHENS of Texas. Would it be anything like the forest-reserve bill, by which seventy or eighty million acres of land in the United States have been tied up?

Mr. LACEY. Certainly not. The object is entirely different. It is to preserve these old objects of special interest and the Indian remains in the pueblos in the Southwest, whilst the other reserves the forests and the water courses.

40 Cong. Rec. 7888 (June 5,1906 ). This exchange is quoted by James Rasband for the proposition that an earlier version of the Antiquities Act's focus was so limited. See James R. Rasband, Stroke of the Pen, Law of the Land?, 63 ROCKY MT. MN. L. INST. 21-1 (2017). But the colloquy took place on the final day of House debate and it expressly references the final language on the permissible scope of a monument. 
immune from court challenge, and no court has ruled that all such claims are precluded, it does not follow that one President's supposedly limitless discretion as to a monument's original size permanently trumps any subsequent President's determinations regarding the same monument. Though we don't think the President's revision power is limited to correcting past abuses, he may have a continuing obligation to do so. ${ }^{37}$

Regarding the judicial process, the Supreme Court has passed on or assumed the validity of some large monuments, though none approaching the hundred million acre marine monuments by the past three Presidents. In 1920, the Supreme Court relied on the validity of the 1908 reservation that created the Grand Canyon National Monument in rejecting a private mining claim in Cameron v. United States. ${ }^{38}$ The size of the original monument designation was not directly at issue, perhaps because Congress had recently converted the monument into a national park by statute. Yet the Supreme Court also has considered issues relating to two other large monuments or former monuments. ${ }^{39}$ While the original monuments' sizes were not challenged in any of these cases, it is not clear whether the courts will invalidate large geological monument designations due to their size alone. ${ }^{40}$ Even so, the Antiquities Act's primary motivation and historical context is still legally relevant to refute the arguments of those who would limit a President's revocation power based on a selective and misleading statement about its supposed purpose to protect vast, park-like vistas. That simply was not Congress's original intent.

This history of the period is relevant to help resolve one other interpretive question that has arisen with respect to purported monuments on the high seas: the meaning of the textual requirement that the "lands" being reserved under the monument designations are "owned or controlled" by the United States. Three of the most important Indian lands where prehistoric artifacts might be looted were not even states in 1906; Arizona, New Mexico, and Oklahoma were then federal territories. Hawaii was only recently annexed and organized as a territory,

\footnotetext{
37. See the later discussion infra Part III.

38. 252 U.S. 450 (1920).

39. See Alaska v. United States, 545 U.S. 75 (2005); United States v. California, 436 U.S. 32 (1978).

40. See Tulare Cty. v. Bush, 306 F.3d 1138, 1142 (D.C. Cir. 2001) (rejecting a challenge to the 327,769-acre Giant Sequoia National Monument as not constituting "the smallest area compatible with proper care and management" of the objects being protected). Although the Supreme Court has not ruled on a challenge to the excessive size of a monument, the courts have deferred to many presidential determinations under the Act, and challengers may have to show an abuse of discretion to prevail on a size-based claim. Yet Tulare County may be distinguishable in future challenges since the court held that the challengers failed to establish a factual basis for their size claim, not that such a claim was barred. Consider one justification that President Obama provided for creating the recent Bears Ears National Monument: that scattered archeological sites would be easier to protect with a broad monument designation. Although Obama's proclamation also cited the area's cultural, geological, and historical significance, it is unclear how isolated archeological sites are better protected by a massive 1.35 million acre monument designation that incorporates all of them than previously, especially when the same two federal agencies (the U.S. Forest Service and the Bureau of Land Management) will each manage the same areas after the designation as before it.
} 
and Alaska was still a sparsely settled American "district" after the gold rushes of the 1890 s-not yet an official federal territory. These were areas of exclusive federal ownership and control, but some of the United States' ownership right was burdened with a trust for the benefit of Native American tribes or indigenous peoples of Alaska or Hawaii. ${ }^{41}$ Other areas of the West were also held by the United States in trust for the benefit of Native American tribes, so almost complete control (without unfettered fee simple absolute title) was potentially at issue for many sites where antiquities might have been found.

\section{B. Academic Literature}

Most of the literature on presidential uses of the Antiquities Act addressed the Clinton Administration's monument designations. Recent work has also emerged in response to an earlier version of this Article released by the American Enterprise Institute, ${ }^{42}$ and to President Trump's subsequent executive orders in late April to the Secretaries of Interior and Commerce to review and make recommendations on whether to alter the largest and most controversial monument designations from the last twenty-one and ten years, respectively (the latter period for marine monuments). ${ }^{43}$

Much legal scholarship prior to 2017 defends a broad interpretation of the Antiquities Act that supports virtually unchecked presidential discretion to create or expand vast national monuments because it enables environmental preservation without the delay and compromise of politics. ${ }^{44}$ Scholars dismiss criticism that the Act is meant only to protect manmade objects and landmarks of historical import; ${ }^{45}$ they argue that the purpose of the Act is to provide an efficient, immediate mechanism for environmental preservation of both

41. Richard A. Monette, Governing Private Property in Indian Country: The Double Edged Sword of the Trust Relationship and Trust Responsibility Arising out of Early Supreme Court Opinions and the General Allotment Act, 25 N.M. L. REV. 35, 57 (1995)

42. John Yoo \& Todd Gaziano, Presidential Authority to Revoke or Reduce National Monument Designations, AM. ENTER. INST. (2017), http://www.aei.org/publication/presidentialauthority-to-revoke-or-reduce-national-monument-designations/ [http://perma.cc/PX7W-UD3E] .

43. Exec. Order No. 13,792, 82 Fed. Reg. 20,429, 20,430 (April 26, 2017) (directing the Secretary of Interior to review monuments or expansions of them since 1996 that are larger than 100,000 acres or those "made without adequate public outreach and coordination with relevant stakeholders," and directing the Secretary to make interim and final "recommendations for ... Presidential actions, legislative proposals, or other actions consistent with law as the Secretary may consider appropriate . ...."); see also Exec. Order No. 13,795, 82 Fed. Reg. 20,815, 20,816 (April 28, 2017) (directing the Secretary of Commerce, in consultation with other relevant cabinet secretaries, to review and make recommendations on "all designations and expansions of Marine National Monuments under the Antiquities Act of $1906 \ldots$.. designated or expanded within the 10 -year period prior to the date of this order").

44. See, e.g., Kelly Y. Fanizzo, Separation of Powers and Federal Land Management: Enforcing the Direction of the President Under the Antiquities Act, 40 ENVTL. L. 765, 819 (2010); Roberto Iraolo, Proclamations of National Monuments and the Scope of Judicial Review Under the Antiquities Act of 1906, 29 WILLIAM \& MARY ENVTL. L. \& POL'Y REV. 159 (2004).

45. See Christina Klein, Preserving Monumental Landscapes Under the Antiquities Act, 87 CORNELL L. REV. 1333, 1365 (2002). 
manmade and natural sites. ${ }^{46}$ They justify the broad presidential use of the Antiquities Act on the law's protective purpose, its broad language, and the perceived acquiescence of the other branches to the expansion of presidential power. ${ }^{47}$ They argue that the statute recognizes the necessity of a strong executive to protect historic and natural sites alike, and that the other branches have silently acquiesced in the President's broad uses of the delegated power. ${ }^{48}$ Indeed, it seems that courts have generally deferred to the President in interpreting the extent of his power to withdraw public lands from use. ${ }^{49}$ Environmental law scholars generally conclude that such deference is consistent with separation of powers principles because the question of land designation should be left to a power struggle between Congress and the President, rather than to judicial review. ${ }^{50}$

Other scholars argue that there is room for debate about whether expansive designations by Presidents actually comport with the language and purposes of the Antiquities Act. For example, Scott Nishimoto predicts that the "ordinary meaning" of the Act's language would likely support deference to the President's judgment, but an originalist approach requires a designation "to protect only small geographical areas of land."51 James Rasband, furthermore, argues that the Antiquities Act should be amended to "require public participation in the withdrawal process and mandate explicit consideration of impact on local communities." 52 Rasband concedes the allure of using the Antiquities Act to avoid the political hassle of trying to get a land protection bill through Congress. ${ }^{53}$ However, he also admits to being "troubled" by "defending an act whose primary value is as a tool to circumvent Congress" and to avoid resistance

46. See, e.g., Fanizzo, supra note 44, at 819; Klein, supra note 45, at 1395; Iraolo, supra note 44, at 185-86; Sanjay Ranchod, Note, The Clinton National Monuments: Protecting Ecosystems with the Antiquities Act, 25 HARV. ENVTL. L. REV. 535, 539, 574 (2001).

47. Klein, supra note 45 , at 1383 (noting that the "seeds of preservationism" sit in the plain language of the Act, both in the breadth of the landscapes it purports to protect and in the expansive grant of power that it bestows upon the president).

48. See Fanizzo, supra note 44, at 794; Klein, supra note 45, at 1336; Iraolo, supra note 44 , at 185-86; Ranchod, supra note 46 , at 582.

49. See Iraolo, supra note 44 , at $184-86$ (analyzing the case law interpreting the grant of discretion under the Act and finding that courts have never found a monument designation to be inconsistent with the statute's language); Fanizzo, supra note 44, at 819 , argues that the courts' broad statutory construction is also prudential. Presidents are best positioned to best determine the area of land for withdrawal and its best management. Moreover, they are much better able to effect a unified policy than a politically deadlocked Congress.

50. Iraolo, supra note 44, at 188-89.

51. Scott Y. Nishimoto, President Clinton's Designation of the Grand CanyonParashant National Monument: Using Statutory Interpretation Models to Determine the Proper Application of the Antiquities Act, 17 J. ENVTL. L. \& LiTIG. 51, 86-89 (2002).

52. James Rasband, Utah's Grand Staircase: The Right Path to Wilderness Preservation?, 70 U. COLO. L. REV. 483, 553 (1999).

53. Id. at 550 . 
by local interests. ${ }^{54}$ Other scholars, at least prior to 2017 , disagreed that public participation is desirable. Squillace argues that it is "the very lack of process that has allowed the Antiquities Act to serve the American people so well." Lin maintains that voters can hold the President accountable at the ballot box if they disagree with his use of the Antiquities Act power. ${ }^{56}$ Congress has sufficient mechanisms to check the President because it may withhold funding for a monument's administration or can reverse the designation outright. ${ }^{57}$

Environmental law scholars, however, are divided over whether a President may revoke a monument designated by a predecessor. One group believes that reversal is prohibited, while a second group considers the question still open. In a June 2017 Virginia Law Review Online essay, Squillace, Biber, Bryner, and Hecht argued that the Trump administration could not undo past Antiquities Act designations. ${ }^{58}$ Even though the courts have not directly addressed the question, they argue that statutory silence on reversal indicates that Congress only intended to delegate the power to designate monuments. ${ }^{59}$ In other contemporaneous statutes, such as the Pickett Act and the Forest Service Organic Administration Act, they argue, Congress twice expressly included a power to reverse earlier presidential actions on public lands. ${ }^{60}$ Second, they rely on a 1938 opinion by Attorney General Homer Cummings as an authoritative interpretation of the Act. In rejecting FDR's proposal to reverse the designation of the Castle Pinckney National Monument, Cummings opined that the Act "does not authorize [the President] to abolish [national monuments] after they have been established."

The earlier public land management acts mentioned above, however, have no bearing on the general presidential ability to undo past executive acts, especially when the statute is silent as to revocation. The Pickett Act of 1910, for example, allowed the President to withdraw federal lands from settlement and reserve them for certain purposes. ${ }^{62}$ The statute also provides that the withdrawal

54. Id. at 557 (recommending that in order to make Antiquities Act designations more democratically legitimate, there should be either an amendment to require public process or an "ethical code" to guide the withdrawal process in a way that respects the rights and voices of those affected).

55. Mark Squillace, The Monumental Legacy of the Antiquities Act of 1906, at 476 (Legal Studies Res. Paper Series Working Paper No. 07-16, 2007). In his view, public participation would be captured by private interests and political ideology and thus would not be helpful to the President in determining whether particular land should be withdrawn. Id. at 476 . More broadly stated, Squillace's position is that "public participation should not be allowed, or at least should be carefully regulated, when it has the potential to undermine the common good by interfering with the Government's capacity to make decisions that are designed to promote the public interest." Id. at 577.

56. Albert C. Lin, Clinton's National Monuments: A Democrat's Undemocratic Acts, 29 ECOLOGY L.Q. 707, 726-28 (2002).

57. Id. at 728 .

58. Squillace et al., supra note 11.

59. Id. at 58-59.

60. Id. at 58-59; accord Klein, supra note 45 , at $1387-89$. We contest this claim immediately below as to the Pickett Act and explain its inconsequence as to the Forest Service Organic Administration Act.

61. Id. at 59 (quoting 39 Op. Att'y Gen. 185, 185-86 (1938)).

62. Pickett Act, Pub. L. No. 61-303, 36 Stat. 847 (1910) (repealed 1976). 
would remain in effect "until revoked by him [referring to the President] or by an Act of Congress." ${ }^{.63}$ Contrary to the characterization by Squillace, that last phrase of the Pickett Act did not expressly grant the President power to revoke prior withdrawals. It assumes that power exists and, instead, clarifies that any withdrawal continues indefinitely until such revocation or subsequent act of Congress. This example supports the general presumption that the grant of a withdrawal power includes the power of revocation.

The Forest Service Organic Administration Act does expressly authorize the President "to modify any Executive order that has been or may hereafter be made establishing any forest reserve, and by such modification may reduce the area or change the boundary lines of such reserve, or may vacate altogether any order creating such reserve." 64 From this provision, Squillace and his colleagues imply that the President lacks revocation authority under the Antiquities Act because it is not granted explicitly. ${ }^{65}$ But the complete and original text of the Forest Service Act paints a very different picture. It explains that Congress wanted to remove all doubt about the presidential revocation power, not to imply that it exists only by express language. The original revocation provision reads in full as follows:

Provided, that, to remove any doubt which may exist pertaining to the authority of the President thereunto, the President of the United States is hereby authorized and empowered to revoke, modify, or suspend any and all Executive orders and proclamations or any part thereof, from time to time as he shall deem best for the public interests. ${ }^{66}$

The original language Congress used in the Forest Service Act suggests that most members of Congress had no reason to doubt the President's revocation authority flowed from the withdrawal power, but that someone wanted to make abundantly clear that the President could withdraw public lands for protection and revoke forest reserves by executive order. The Pickett Act and the Forest Service Act, on balance, support the presumption that presidential revocation authority exists where the law is simply silent, but they add little either way. ${ }^{67}$

More significantly, the critics of presidential power cannot point to any court decision or other controlling authority that holds that revocation authority does not exist when a statute is silent. Indeed, they urge a unique presumption for the Antiquities Act that runs counter to the widespread interpretation of

\footnotetext{
63. Id. at 847 .

64. Forest Service Organic Act of 1897 , ch. 2, 30 Stat. 34,36 (codified as amended at 16 U.S.C. $\$ 475(2018)$ ).

65. See Squillace et al., supra note 11 , at 58

66. Forest Service Organic Act of 1897, 30 Stat. at 34 (emphasis added).

67. See Jonathan Wood, Law Professors Argue the President Can't Revoke National Monuments, PAC. LEGAL FOUND. BLOG (May 16, 2017), http://pacificlegal.org/law-review-articleimplicitly-argues-not-even-congress-can-reverse-national-monuments [https://perma.cc/8FP5-2DXA] (reviewing the legislative history of the Pickett Act and the Forest Service Act with the same conclusion).
} 
numerous other statutes that authorize or require the issuance of protective regulations and contain no express provision on repealing or replacing regulations. If the presumption urged by the critics of presidential power applied elsewhere, almost all regulations would operate as a one-way ratchet that would prevent future administrations from modifying or repealing past rules and the modern administrative state would operate very differently.

As explained in Part II, the courts have made clear that, as to scores (perhaps hundreds) of statutes that grant protective rulemaking authority to the executive, the power to modify or rescind previously issued regulations exists even when the underlying statute is silent as to that power-as long as the same procedures are followed to revoke or modify the regulation as were used to issue it. $^{68}$ The D.C. Circuit so held without canvassing how many other statutes granting the power to issue regulations expressly provided the power to modify or repeal them. In short, that Congress expressly granted the power to repeal a rule in some statutes was of no moment in determining that the power exists when Congress is silent.

Others argue that the standard administrative law practice of withdrawing existing regulations or executive orders by issuing a new one should not apply to the Antiquities Act. Klein, for example, argues that there is a qualitative difference between executive orders involving "minor policy initiatives," which are subject to reversal, and major declarations like Antiquities Act monuments, for which a reviewing court would hesitate to "countenance the casual reversal." "69 cites INS v. Chadha for support for the general proposition "that when the executive branch acts pursuant to a lawful delegation of authority, such action can be revoked only by an act of Congress." ${ }^{70}$ Rasband agrees that no such reversal power could be implied merely from the explicit delegation of authority to designate monuments in the first place. ${ }^{71}$

Squillace and his co-authors also maintain that interpreters must take note of subsequent congressional enactments in the area, specifically the Federal Land Policy and Management Act of 1976 (FLPMA), ${ }^{72}$ in interpreting the earlier Antiquities Act. ${ }^{73}$ The FLPMA replaced the earlier statutes, such as the Pickett Act, that had expressly authorized the withdrawal and management of public lands with a new regime that expressly authorized the Secretary of the Interior

68. See, e.g., Pennsylvania v. Lynn, 501 F.2d 848, 855-56 (D.C. Cir. 1974).

69. Klein, supra note 45 , at 1389 . Would Klein and other environmental scholars characterize the "Waters of the United States Rule" and the "Clean Power Plan," regulations under the Clean Water Act and Clean Air Act, respectively, that President Trump has taken steps to withdraw, as "minor" compared to some national monument designations of an historic civil rights site that cover less than an acre? On what basis are such regulations minor?

70. Id.

71. James R. Rasband, The Future of the Antiquities Act, 21 J. LAND RES. \& ENVTL. L. $619,625(2001)$. et seq. (2018)).

72. Pub. L. No. 94-579, 90 Stat. 2743 (1976) (codified as amended at 43 U.S.C. $\$ 1701$

73. Squillace et al., supra note 11, at 59-64. 
to reverse earlier public lands decisions. ${ }^{74}$ But the FLPMA neither touched the Antiquities Act nor subjected it to this new reversal provision. It expressly prohibited the Secretary from modifying or revoking any national monument under the Antiquities Act. Working off of legislative history from a House committee report, they argue that Congress sought to "specifically reserve to the Congress the authority to modify and revoke withdrawals for national monuments created under the Antiquities Act." conclude, "FLPMA left unchanged the President's authority to create national monuments under the Antiquities Act, and included language confirming that Congress alone may modify or abolish monuments."76

Part II will explain in greater detail why these scholars are mistaken.

\section{A General Discretionary Power to Revoke Prior Designations}

This Part argues that Presidents have a general power to reverse the designation of national landmarks by their predecessors. It first criticizes the main authority for the proposition that such designations are permanent: the 1938 Justice Department opinion of Attorney General Homer Cummings. It then sets out the general principle of constitutional and administrative law that the executive branch and, indeed, the other branches of government, can undo their past decisions by following the same legal process. Finally, it explains that in the delegation of its constitutional power over public lands, Congress could have attempted to introduce a one-way ratchet into the Antiquities Act. But it chose not to do so, perhaps because that would have been constitutionally questionable or, more likely, because it simply wanted the President to be free to revoke earlier monument designations. Either way, the executive's use of delegated power survives only so long as future Presidents choose not to reverse it-with the Antiquities Act as well as any other administrative statute.

\section{A. The Cummings Opinion}

Much of the existing scholarship on the Antiquities Act relies heavily on the 1938 Cummings opinion. Cummings advised President Roosevelt that he could not revoke the designation of the Castle Pinckney National Monument because the Antiquities Act granted no such power. ${ }^{77}$ Although the opinion has been cited in later government documents ${ }^{78}$ and by legal commentators, ${ }^{79}$ no

74. Id.

75. Id. at 63

76. Id. at 60 .

77. Cummings Opinion, supra note 13.

78. The Solicitor of Interior cited the opinion in 1947 but for a different proposition, namely that the President can alter the boundaries of a national monument. See National Monuments, 60 Interior Dec. 9 (1947).

79. See, e.g., Squillace et al., supra note 11 , at 58 . 
court has ruled on the President's revocation power or cited the opinion, in part because no President has attempted to revoke a prior designation. ${ }^{80}$ We believe that the Cummings opinion makes errors of constitutional and statutory interpretation and should not serve as a precedent for future Presidents.

As we explain below, it is possible the Trump administration has already overruled it in an unpublished opinion. Critics of executive power have read it as not only barring revocation of a national monument but also barring a significant reduction to an existing monument. To the extent that is a fair reading of the opinion, the administration must have superseded it with President Trump's proclamation in December 2017 significantly reducing the Bears Ears National Monument. ${ }^{81}$

While brief, the Cummings opinion served for years as the primary legal authority for the claim against a revocation power in the Antiquities Act. In their recent Virginia Law Review essay, Squillace et al. further describe the Cummings opinion as "the single authoritative executive branch source interpreting the scope of Presidential power to revoke monuments designated under the Antiquities Act." ${ }^{82}$ Similarly, Kelly Fanizzo states that "it appears the only legal authority directly on this issue [of revocation] is a 1938 Opinion of the Attorney General." "83 These scholars recognize the opinion's conclusion that statutory silence implies congressional intent not to delegate authority to undo past monument designations. Squillace, for example, adopts the Cummings logic in arguing that the Antiquities Act created a "one-way authority to create, but not revoke or modify, national monuments," because of "the impetus to pass the law" and "the concern that spectacular public land resources might be harmed before Congress could act to protect them." 84

The Congressional Research Service (CRS), Congress's research arm, takes notice of that view. In a 2016 report, CRS observed that "because the authority for national monument proclamations is provided by a specific statute [to the President]," rather than directly by the Constitution, "the authority to

80. The Attorney General was first authorized to issue legal opinions to the President under the Judiciary Act of 1789, now codified at 28 U.S.C. $\$ \S 511-13$ (2018), and to other agency heads by that act and other delegations of authority from the President. Attorney General opinions, and those that now are issued by the Department of Justice (DOJ) Office of Legal Counsel (OLC), are binding on executive branch agencies. In contrast, a President is free to disregard them-especially if he concludes that his oath to take care that the laws are faithfully executed conflicts with such an opinion. Nevertheless, prudence dictates that the President request that his own attorney general reexamine such opinion, perhaps with the assistance of OLC, which became an independent division of the DOJ in 1951 and is commissioned to provide serious legal analysis on such matters. The existence of Cummings's 1938 published opinion is an internal hurdle that any administration should address, preferably with another published opinion, either affirming, qualifying, or overruling Cummings's advice.

81. Proclamation 9681 - Modifying the Bears Ears National Monument, 2017 DAILY COMP. PRES. DOC. 2 (Dec. 4, 2017).

82. Squillace, et al., supra note 11 , at 58 .

83. Fanizzo, supra note 44 , at 822 .

84. Mark Squillace, The Monumental Legacy of the Antiquities Act of 1906, 37 GA. L. REV. 473, 553-54 (2003). 
revoke such proclamations has been interpreted to be more limited." 85 These scholars read the Cummings opinion to bolster their claims that the Antiquities Act's silence implies that Congress intended to withhold the authority to reverse the designation of a landmark from its delegation of authority to the President.

Cummings addressed whether the Secretary of the Interior could abolish the Castle Pinckney National Monument in Charleston, South Carolina, and transfer the land to the War Department. Under the Antiquities Act, President Calvin Coolidge had formed the monument in 1924 from a U.S. fort that had existed in Charleston harbor since the early 19th century. As Cummings observed, the Antiquities Act contained no clear textual authorization to "abolish" national monuments. "If the President has such authority, therefore, it exists by implication." 86

Cummings concluded that without clear authorization from Congress, President Roosevelt could not reverse the designation of Castle Pinckney. In a brief opinion, he relied on two grounds. First, he believed U.S. Attorney General Edward Bates had settled the issue in an 1862 opinion that found that the President could not return a military reservation to the pool of general public lands available for sale. ${ }^{87}$ Second, he compared the Antiquities Act to other federal laws governing temporary withdrawals of federal land or forests, which explicitly provide for presidential modification of past designations. ${ }^{88}$ In addressing past practice, which he conceded supported a right to reduce the size of national monuments, Cummings argued that "it does not follow from his power so to confine that area that he has the power to abolish a monument entirely." 89

Cummings's opinion errs in some obvious respects and is too cursory to be persuasive. ${ }^{90}$ One major flaw, not examined by scholars who use the opinion as precedent, is Cummings's misreading of Attorney General Bates' 1862 opinion, ${ }^{91}$ which could not directly bear on the meaning of a statute passed fortyfour years in the future. Bates addressed whether an administration in the 1840s could rescind a military reservation in Illinois for which Congress had appropriated money and on which a fort had been constructed. He found that the statute delegating to the President the power to designate land for military

85. ALEXANDRA M. WYATT, CONG. RESEARCH SERV., R44687, ANTIQUITIES ACT: SCOPE OF AUTHORITY FOR MODIFICATION OF NATIONAL MONUMENTS 3 (Nov. 14, 2016).

86. Cummings Opinion, supra note 13 , at 186.

87. $1 d$.

88. Id.

89. Id. at 188 .

90. We published our first detailed critique of Cummings's opinion in March 2016, in an American Enterprise Institute paper. The President's national monument review executive order the following month should have triggered a further legal review of Cummings's opinion within the administration. Whether a newer opinion was drafted or not, the Justice Department's views are likely to be asserted in the litigation over the Bears Ears and Grand Staircase Escalante National Monuments. Yoo \& Gaziano, supra note 42.

91. Rock Island Military Reservation, 10 Op. Att'y Gen. 359 (1862). 
purposes did not include a power to withdraw the designation. Bates seemed to believe that delegated power, once used, could not be activated again to reverse the decision: "A duty properly performed by the Executive under statutory authority has the validity and sanctity which belong to the statute itself, and, unless it be within the terms of the power conferred by that statute, the Executive can no more destroy his own authorized work, without some other legislative sanction, than any other person can." 92 In designating a military reservation, the President had effectively exhausted the delegation of power from Congress.

But the 1862 opinion contains important factual and legal distinctions from the Antiquities Act question. For example, Bates states that he is interpreting military reservation authority under "early acts of Congress" and an "act of 1809," which provided appropriations for constructing forts "for the protection of the northern and western frontiers." $" 93$ Of course, these statutes could have no precedential value for interpreting the Antiquities Act, and Cummings does not explain why they should. Perhaps most importantly, the 1862 opinion acknowledges that the military reservation itself could be abandoned by the War Department, which is the equivalent of revoking a land reservation under the Antiquities Act. ${ }^{94}$ It also relies on the fact that in 1858 , Congress had specifically repealed any statutes that authorized the sale or transfer of military sites to the public. ${ }^{95}$ No such express statutory prohibition on the presidential withdrawal of national monument status exists in the Antiquities Act.

Instead, Bates focuses on whether an abandoned military reservation and its buildings would be subject to "entry or preemption by settlers." This provision refers to the Preemption Act of 1841, which allowed squatters on federal land during the 1840 s and 1850 s to secure title to it at a low price (preempting a general public sale) if they also worked it for a number of years. ${ }^{97}$ To conclude that squatters could not simply enter the military reservation and secure title to it "by preemption," Bates relies on a combination of factors that are distinguishable from revoking a monument designation under the Antiquities Act, including the unnamed "early acts of Congress," which authorized its initial selection as a military reservation; the 1809 appropriation for military forts on the frontier; that Fort Armstrong had been constructed and occupied for more than two decades; that its buildings were still in good order; that other laws governed the sale of abandoned military property; and more recent acts of

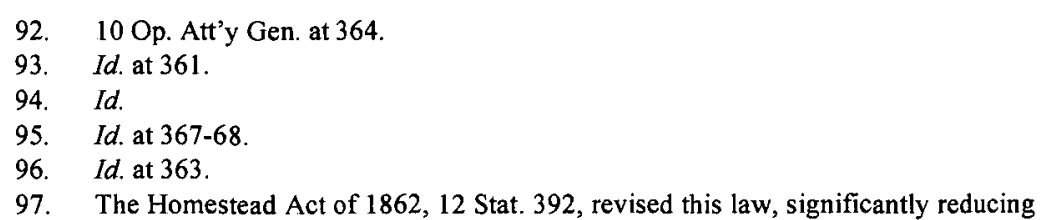
the number of "preemption" claims. But Bates was addressing the rights of settlers who may have occupied the former military property before 1862 . 
Congress relating to the particular piece of property, which assumed it was not subject to preemption by settlers. ${ }^{98}$

Cummings did not acknowledge these and other potential distinctions. Bates found that separate laws governed the management and disposal of military property from the homesteading or preemption laws that had populated Kansas and Nebraska. It is not surprising that interpreting different statutes yields different results, but even so, Bates conceded that an improved military reservation could be abandoned and sold, just not pursuant to the Preemption Act of 1841. Cummings mistakenly read the 1862 opinion for the proposition that once land is reserved under any act of Congress, that reservation can never be rescinded. In contrast to the question Bates addressed, revoking a monument designation under the Antiquities Act would not change the federal ownership of the land at issue.

For this reason and others, the portion of the 1862 opinion that Cummings quoted is especially questionable as applied to land reservations under the Antiquities Act. The quoted language also contains several inapt analogies and propositions of law. For example, Cummings quotes the opinion for the proposition that the "power to execute a trust, even discretionarily, by no means implies the further power to undo it when it has been completed." 99 The italicized phrase is misleading. Not every grant of a power to create something must include the power to abolish it, but many do. Special circumstances might make revoking certain acts impossible, or that power might be withheld, but a presumption of revocability is often implied if the grant is silent. ${ }^{100}$

Indeed, reliance on trust law should have led to the opposite conclusion, at least under the Antiquities Act. Under general trust principles, at least in the twentieth and twenty-first centuries, the power to create a trust includes the power to revoke it when the settlor retains an interest in it, unless the trust is expressly irrevocable under the original grant of authority. ${ }^{101}$ If a court applied trust law principles to the Antiquities Act, we think it would conclude that the President retains an interest in the monument designations he or a predecessor creates, including the duty to manage them, to issue and enforce regulations to protect them, and to adjust their borders from time to time with subsequent presidential proclamations. Moreover, the broader principle of trust law is that the party creating the trust has the power to decide whether it is revocable; the discretionary nature of the President's power under the Antiquities Act and certain textual cues suggest Congress did not intend to make all monument reservations permanent.

98. 10 Op. Att'y Gen. at 360-62.

99. Cummings Opinion, supra note 13, at 87 (emphasis added).

100. See UNIF. TRUST CODE $\S 602$ (a) (UNIF. LAW COMM'N 2010) ("Unless the terms of a trust expressly provide that the trust is irrevocable ....").

101. See RESTATEMENT (THIRD) OF TRUSTS $\$ 63$ (AM. LAW INST. 2003). 
Cummings's reliance on Bates's analysis fares no better than his reliance on trust law. It is true that a President has no general constitutional authority to manage federal land, although he may have some limited powers as commander in chief or under other statutory grants of authority. That, however, does not answer whether Congress' grant of authority in "early acts of Congress" or the Antiquities Act of 1906 to make reservations includes the power to rescind or revoke them. Indeed, Bates conceded that military reservations could be abandoned; he just believed the land would not be subject to "preemption by settlers." In the context of the Antiquities Act, a.President could rescind or amend the parcels of land reserved for a given monument without repealing the underlying monument designation. There is no evidence that Congress intended to withhold either revocation power in the Antiquities Act, let alone both of them.

Bates's final proposition is equally circular as applied to the Antiquities Act. He asserts that reading the unnamed "early acts of Congress" and especially the 1809 appropriation to allow "preemption by settlers" would effect a repeal of the underlying laws: "To assert such a principle is to claim for the Executive the power to repeal or alter an act of Congress at will."102 That Presidents cannot unilaterally repeal statutes does not answer whether Congress included the power both to make and revoke reservations in the original grant of authority under the Antiquities Act.

Without the Bates opinion for support, Cummings's only original argument starts and ends with one of the Antiquities Act's purposes: "to preserve ... objects of national significance for the inspiration and benefit of the people of the United States." 103 Cummings then immediately concludes, ipse dixit, that "[f] or the reasons stated above, I am of the opinion that the President is without authority" to issue a proclamation revoking the Castle Pinckney National Monument. ${ }^{104}$ Casual reliance on one of the Act's purposes, and one that was not set forth in the Act itself, adds nothing of weight. It does not explain why revoking the monument at issue was inconsistent with the general purpose of preserving objects of national significance. ${ }^{105}$ What if the President determined, for example, that no objects of national significance remained at a given site?

Cummings also does not fairly consider other purposes. If a textual ambiguity justified a resort to legislative materials, the full record would show that the Act's primary purpose was to provide a power to the President to prevent the destruction and looting of artifacts until they were excavated and safeguarded or until Congress could consider long-term measures regarding the site. This more complete statement of purposes highlights that the passage of time matters and that a later President could reasonably conclude that Congress declined the

102. 10 Op. Att'y Gen. at 364 .

103. Cummings Opinion, supra note 13 , at 189.

104. Id.

105. Cf. Skidmore v. Swift \& Co., 323 U.S. 134, 140 (1944) (rendering deference to agencies contingent on "the thoroughness evident in its consideration, the validity of its reasoning, its consistency with earlier and later pronouncements, and all those factors which give it power to persuade"). 
opportunity to legislate on the land or objects in an earlier monument designation or that they were now safeguarded, such as by excavation and display in a museum.

\section{B. The General Power of Reversal Inherent in American Law}

A proper analysis of the revocation power under the Antiquities Act should also consider other grants of authority to the President in the Constitution and other statutes, judicial decisions, and constitutional practice. Cummings made no effort to do that in 1938, and the range of presidential action the courts have upheld, even under older delegations dating to the post-Civil War era, is now more robust than in early twentieth-century jurisprudence.

A background principle of American law we identify herein is that the authority to execute a discretionary government power usually includes the power to revoke it-unless the original grant expressly limits the power of revocation. The Constitution provides important examples of this background principle, but the workings of the modern administrative state provide the most analogous statutory examples.

There are scores of congressional statutes authorizing or requiring the executive branch to issue regulations and take other actions to protect the environment, worker safety, consumer product safety, highway safety, airline safety, consumer financial protections, food and drug protections, and many others. When Congress gives an agency the authority to issue regulations, particularly discretionary authority, it is presumed that the agency also has the authority to repeal those regulations. ${ }^{106}$ This principle is especially true when the regulation has been shown to be contrary to the purposes underlying the statute. ${ }^{107}$ Section 4 of the Antiquities Act grants three department secretaries the power to publish "from time to time uniform rules and regulations for the purpose of carrying out the provisions of this Act." 108 Although Congress did not expressly state that the officials can repeal or significantly alter their regulations once they are published "from time to time," that is presumed by law. The broader power of revocation of national monuments by the President should also be strongly presumed.

Squillace and his co-authors argue that other federal land management statutes from the turn of the last century expressly granted the power to reverse a land withdrawal decision, implying that the power is denied otherwise. ${ }^{109}$ As we described earlier, critics of presidential revocation adopt a default rule that statutory silence shows congressional intent to withhold the power to undo past exercises of delegated authority, but they have no authority for that

106. See, e.g., Commonwealth of Pa. v. Lynn, 501 F.2d 848, 855-56 (D.C. Cir. 1974).

107. See id.

108. See Antiquities Act of 1906, Pub. L. 59-209, 34 Stat. 225 (1906) (codified at 54 U.S.C. $\$ \S 320301-03(2018)$ ).

109. Squillace et al, supra note 11 at 58 . 
counterfactual intention. ${ }^{110}$ Even if they had numerous examples of express revocation authority, critics cannot point to any court decision or other controlling authority holding that revocation authority does not exist when a statute is silent. In the absence of any such holding, the presumption against revocation falls apart, especially in light of the general executive and administrative practice that textual silence implies the power to revoke as well as act.

Beyond that, the meager examples cited by Squillace and his co-authors of express revocation authority are not as strong as the critics maintain and, upon careful review, mildly support the presumption of revocability if they have any bearing on the issue at all. As explained previously, the text of the Pickett Act does not affirmatively authorize the President to revoke a withdrawal. ${ }^{111}$ Instead, it assumes the power exists and merely confirms that the withdrawal remains in effect indefinitely until the President exercises that reserved power. That is hardly an express grant of revocation authority, let alone reason to suspect that the President does not have such authority when Congress is silent. Moreover, if the Pickett Act argument were valid, the President wouldn't be the only constitutional actor unable to revoke a monument designation. The Pickett Act also specifically mentions Congress' power to revoke a withdrawal ("until revoked by him [the President] or an Act of Congress"). ${ }^{12}$ There is no express reference to the President's or Congress's revocation authority in the Antiquities Act. If silence is enough to bar the President from revoking a national monument designation, it would also mean that Congress could not do so either. No Congress, of course, can bind a future Congress in the exercise of its constitutional authority. ${ }^{113}$

In the Forest Service Act, Congress expressly granted a revocation power, but the original text, not quoted by the critics, shows that Congress thought the revocation power already existed and was simply seeking to remove any doubt. ${ }^{114}$ On balance, these two examples suggest a congressional awareness that the President is generally able to reverse executive directives.

But beyond one immaterial example of an express revocation provision from an earlier era, Presidents regularly revise or revoke hundreds of executive orders and administrative regulations throughout the administrative state. If the arguments of many scholars were correct, most administrative regulations would also operate as one-way ratchets, not subject to repeal or modification by future Presidents. Many of President Trump's executive orders today and in the years to come, under this logic, would be permanent and binding on all future Presidents. Environmental scholars cannot explain why national landmarks

110. See id. at 57-58; Rasband, supra note 71, at 625 .

111. See supra Section I.B.

112. Pickett Act, Pub. L. No. 61-303, 36 Stat. 847, 847 (1910) (repealed 1976).

113. See Wood, supra note 67.

114. See Forest Service Organic Act of 1897, ch. 2, 30 Stat. 34,34 (codified as amended at 16 U.S.C. $\$ 475$ (2018)), For further discussion, see supra Section I.B. 
should evade the general rule of interpretation and broad sweep of practice, especially when Congress has never passed a law expressly prohibiting revocations. Scholars in every specialized field may believe their subject may have its own unique properties, but administrative law processes should remain trans-substantive across all agencies, unless a statute specifically creates a unique process for that field. In other words, the EPA and Interior Departments should follow the general practices of administrative law, rather than operate according to unique and special environmental administrative procedures, in the absence of specific congressional enactments otherwise.

Constitutional law axioms are equally, if not more, relevant in undermining the argument against a presidential revocation power. An operating principle of the Constitution is that any branch of government can reverse its earlier actions using the same process originally used. Thus, Article I, Section 7, of the Constitution describes the only process for enacting a federal law. A statute must pass through both bicameralism (approval of both Houses of Congress) and presentment (presidential approval). But the Constitution describes no process for repealing a statute. Since the adoption of the Constitution, however, our governmental practice is that Congress may eliminate an existing statute simply by enacting a new measure through bicameralism and presentment.

Under the logic of the opponents of presidential revocation, however, Congress could not repeal previous statutes because of the Constitution's silence. While passage of an earlier law may make its repeal politically difficult, due to the need to assemble majorities in both Houses and the requirement of presidential signature, no Congress can bind future Congresses in the use of their legislative power. ${ }^{115}$ This point seemed so obvious at the time of the Framing that it merited only passing mention. In addressing the Constitution's allocation of the treaty power, for example, John Jay observed: "They who make laws may, without doubt, amend or repeal them."

This principle applies to all three branches of the federal government. The Supreme Court effectively repeals past opinions simply by overruling the earlier case, though the Constitution does not expressly provide for such reversals. Brown v. Board of Education ${ }^{117}$ famously overruled Plessyv. Ferguson. ${ }^{118}$ While the Court may follow past precedent out of stare decisis, it employs the same procedure to reverse past cases, as Congress does to reverse an earlier statute. Both a precedent and its subsequent overruling decision require only a simple majority of the Justices. No Supreme Court can bind future Supreme Courts.

This rule also applies to the Constitution as a whole. In Article $V$, the Constitution creates an additional process for amending its own text, which

115. See ANTONIN SCALIA \& BRYAN A. GaRnER, REAding LAw: THE INTERPRETATION OF LEGAL TEXTS 278 (2012).

116. THE FEDERALIST No. 64 (John Jay).

117. 347 U.S. 483 (1954)

118. 163 U.S. $537(1896)$. 
requires two-thirds approval by the House and the Senate and then the agreement of three-quarters of the states. Without this additional option in Article V, the Constitution would require the same or very similar process for its amendment as for its enactment (which would have impractically required a new constitutional convention). Reinforcing our point, the Framers decided to set out explicit mechanisms for repealing part of the original constitutional text when they wanted to provide a means that did not mirror the original enacting process.

The same principle applies to the constitutional amendments themselves. The Constitution contains no provision for undoing a constitutional amendment. Instead, the nation has used constitutional amendments to repeal previous constitutional amendments. The 21st Amendment repealed the 18th Amendment, which had declared Prohibition. When the Constitution is silent about a method for repeal, it is assumed that it permits the same process as that of enactment.

The executive branch operates under the same rule. The Framers created an executive who could act unilaterally and with dispatch because the President's swift action was desirable in the execution of his constitutional and statutory responsibilities, ${ }^{119}$ and they wanted each President to be fully accountable to the electorate for his actions without the diffusion of responsibility found in a Privy Council. ${ }^{120}$ By the same token, the same reasons that counsel for unitary executive action in the first instance support its potential unilateral reversal. More importantly, the Framers' careful protection against arbitrary government would be turned on its head if one President could insulate his unilateral policies against reversal by a subsequent President-for then the constitutional difficulty of enacting a statutory override would further entrench a tyrannical executive policy against electoral or statutory change.

Besides the U.S. Constitution itself, the only relatively permanent domestic policies in America are in statutory text. This is by design. The Framers made statutory enactment intentionally difficult to better protect individual liberty against arbitrary government action. ${ }^{121}$ Laws require simultaneous agreement between two Houses of Congress and the President (or a supermajority in both Houses of Congress to override a presidential veto), and that generally necessitates a high level of compromise and political focus. As the Supreme Court observed in INS v. Chadha, "[ $\mathrm{t}]$ he bicameral requirement, the Presentment Clauses, the President's veto, and Congress' power to override a veto were intended to erect enduring checks on each Branch and to protect the people from

119. THE FEDERALIST No. 70 (Alexander Hamilton) ("Energy in the executive is a leading character in the definition of good government ... it is not less essential to the steady administration of the laws.").

120. See THE RECORDS OF THE FEDERAL CONVENTION OF 1787, at 65-74 (Max Farrand ed., 1911) (discussing the debates over a privy council and what would become the Opinion Clause); see also Todd Gaziano, Opinion Clause, in THE HERITAGE GUIDE TO THE CONSTITUTION (2d ed. 2014) (summarizing the debates over a privy council and the conscious choice of the Framers to focus accountability in a unitary executive).

121. See Immigration \& Naturalization Serv. v. Chadha, 462 U.S. 919 (1983). 
the improvident exercise of power."122 Moreover, laws require this consensus and compromise between constitutional actors with three different constituencies and electoral time horizons. Since it takes the same, if not greater political effort and consensus to repeal a statute, they tend to endure. Indeed, America retains many statutory policies the First Congress enacted in 1789 , such as the design of the federal court system in the Judiciary Act of 1789 and the establishment of the four great agencies: War, State, Treasury, and the Attorney General. ${ }^{123}$

By contrast, unilateral executive actions are, and necessarily must be, easy to reverse by a subsequent President. The risks of entrenched executive action are low because of a strong background principle of American law such that any exercise of presidential power is reversible by a subsequent President, unless revocation is impossible, ${ }^{124}$ expressly forbidden by the original grant, ${ }^{125}$ or creates irreversible vested rights. ${ }^{126}$ In particular, we show that there is no exception to this background principle for discretionary monument designations by the President pursuant to the Antiquities Act. Those who seek permanent protections for federal land must go to Congress. Presidential pleading may result in similar protections under executive authority, but his one-sided action may be reversed. ${ }^{127}$

According to these constitutional principles, no President can bind future Presidents in the use of their constitutional authorities. ${ }^{128}$ Presidents commonly issue executive orders reversing, modifying, or even extending the executive orders of past Presidents. No court has ever questioned that authority, even when it is used to implement statutorily delegated powers. Good examples include the successive executive orders of Presidents Gerald Ford, Jimmy Carter, Ronald Reagan, Bill Clinton, George W. Bush, and Barack Obama to specify how the White House would manage and review the congressionally mandated rulemaking process. ${ }^{129}$ It would be anomalous for a particular type of executive

122. Id. at 957 .

123. See, e.g., Judiciary Act of 1789 , ch. 20, 1 Stat. 73 (creating the structure and jurisdiction of the lower federal courts that largely endues today).

124. The bombing of a city during wartime is physically impossible to reverse.

125. For a rare example of a limitation on reversal, see U.S. CONST., art. III, which provides judges with life-time tenure that cannot be reversed by either the appointing or a subsequent President.

126. A pardon creates a vested right against prosecution or criminal sanctions that cannot be reversed even by an Act of Congress. Vested property rights might be reversed but give rise to a claim for just compensation

127. Jonathan Wood first suggested discussing these options as tradeoffs between statutory power and executive action. See James McElfish, Brenda Mallory, Mark Stephen Squillace \& Jonathan Wood, Antiquities Act: Legal Implications for Executive and Congressional Action, 48 ENVTL. L. REP. 10187, 10195-96 (2018) (comments by Jonathan Wood).

128. The only exceptions, noted earlier, are if the earlier act is impossible to reverse, is expressly made irreversible in the original grant (such as life-time tenure for judicial appointees), or creates irreversible vested rights in third parties (such as are created with a pardon).

129. Exec. Order No. 11,821, 39 Fed. Reg. 41,501 (1974); Exec. Order No. 12,044, 43 Fed. Reg. 12,661 (1978); Exec. Order No. 12,291, 46 Fed. Reg. 13,193 (1981); Exec. Order No. 12,866, 58 Fed. Reg. 51,735 (1993); Exec. Order No. 13,258, 67 Fed. Reg. 9385 (2002); Exec. Order No. 13,422, 72 Fed. Reg. 2,763 (2007); Exec. Order No. 13,497, 74 Fed. Reg. 6,113 (2009). 
directive or presidential proclamation to somehow become immune to repeal or amendment by a subsequent President.

The implied ability of Presidents to reverse earlier presidential acts applies beyond the implementation of statutory delegations of authority. Presidents can always reverse their predecessors' exercise of executive power under the Constitution. Presidents regularly add or remove executive branch officers appointed to White House committees or even the cabinet. They have created and eliminated whole offices in the Executive Office of the President. They have increased or reduced the use of cost-benefit analysis in regulatory decisions. In fact, when the Constitution deviates from this lawmaking symmetry, it explicitly does so in the text and in a manner that makes repeal easier than the first affirmative act.

Some critics of presidential power have attempted to distinguish some of the above examples on the grounds that if Congress cannot repeal its own statutes, no entity could, and the same applies to the Supreme Court's reversal of its own opinions. By contrast, they argue that Congress can undo a national monument designation, so it is not necessary for the President to be able to do so. ${ }^{130}$ There are two problems with that analysis. First, the people have an express method of overriding a statute with a constitutional amendment. It is certainly a difficult and uncertain method, but so is seeking a statutory reversal of abusive national monument designations. The second problem is that the courts have allowed unilateral executive revocations or reversals even when Congress could potentially do the same or similar thing by statute.

The most well-known example is the President's removal power. In AngloAmerican constitutional history, the executive power traditionally included the power both to hire and fire subordinate executive officials. The Constitution altered that traditional appointment process. Under Article II, Section 2, the President nominates and, with the Senate's advice and consent, appoints high executive branch officers, judges, and ambassadors. The Constitution, however, does not explicitly address removing an officer, a fact central to the debate in the First Congress over whether to permit the President to fire cabinet officers. As Sai Prakash has shown, Congress accepted that the President had the constitutional authority to remove the chiefs of the first great departments. ${ }^{131}$ The

130. See Rasband, supra note 36 , at 21-17.

131. Saikrishna B. Prakash, New Light on the Decision of 1789, 91 CORNELL L. REV. $1021,1029-34$ (2006) (providing a guide of the various debates and changes in the statutory proposals); see also DAVID CURRIE, THE CONSTITUTION IN CONGRESS: THE FEDERALIST PERIOD 1789-1801, at 3641 (1997) (recounting the debate); JAMES HART, THE AMERICAN PRESIDENCY IN ACTION 1789, 155-89 (1948); ChARLES C. THACH, JR., THE CREATION OF THE PRESIDENCY, 1775-1789, at 140-65 (1923). Some have argued that Congress's actions indicate that the Treasury Department was not even an executive department, but rather an administrative agency outside of direct presidential control. See Lawrence Lessig \& Cass R. Sunstein, The President and the Administration, 94 COLUM. L. REV. 1, 28 (1994). But see Steven G. Calabresi \& Saikrishna B. Prakash, The President's Power to Execute the Laws, 104 YALE L.J. 541, 548 (1994) (concluding that these arguments were off the mark). Indeed, Madison's arguments in the House that the Treasury Department ought to be unified under one secretary accountable to the 
Framing generation understood the Constitution's silence to allow the President to reverse the appointment process, even without congressional consent.

The Supreme Court has firmly recognized this principle. In Myers v. United States, it found that the Constitution implicitly retained the traditional rule that the chief executive could unilaterally undo an appointment without the Senate's approval. ${ }^{132}$ By revoking an official's commission that was issued after Senate confirmation, the President is more clearly negating a specific, deliberative, and official Senate act. Indeed, the Court has recognized that a removal process that mirrored the appointment process-requiring the Senate's advice and consentwould effectively transform an executive branch official into a legislative official, one who could not assume law enforcement functions. ${ }^{133}$ While Humphrey's Executor v. United States ${ }^{134}$ and Morrison v. Olson ${ }^{135}$ permit Congress to limit the President's discretion with a "for cause" requirement, both cases still recognize the basic principle that the President can remove subordinate officers without the Senate's advice and consent. What's interesting about the Meyers example is that we can imagine a different constitution that requires Senate consent to remove a Senate-confirmed officer. Or we can imagine a constitution that allows direct congressional removal, and only congressional removal. The U.S. Constitution, however, does not enshrine congressional supremacy. Instead, it enshrines a separation of powers that presumes one President can reverse his own appointments or those of his predecessors without congressional approval.

A similar dynamic applies to treaties. Under Article II, Section 2 the President makes treaties, subject to the advice and consent of the Senate. As with appointments, the Constitution altered British constitutional practice of the time, which placed treaty-making under the sole control of the Crown. ${ }^{136}$ Again, the Constitution does not explicitly set out the procedure for terminating a treaty. According to the logic of opponents of a presidential reversal power, however, once the federal government entered into a treaty, the United States could not withdraw pursuant to any subsequent action. They should interpret constitutional silence as a decision to withhold treaty withdrawal power from the President, the President and the Senate, and the Congress as a whole. A more reasonable, but still erroneous position is that constitutional silence requires the federal government to use the exact same process for undoing a treaty as for making one: presidential approval subject to the advice and consent of the Senate, and perhaps even the agreement of the foreign partner. In Federalist 64, John Jay

\footnotetext{
President defeats their claim. For some interesting applications of this theme to Congress and the federal courts, see Saikrishna B. Prakash, Removal and Tenure in Office, 92 VA. L. REV. 1779 (2006).

132. 272 U.S. $52(1926)$.

133. See Bowsher v. Synar, 478 U.S. 714 (1986).

134. 295 U.S. 602 (1935).

135. 487 U.S. 654 (1988).

136. See John Yoo, Globalism and the Constitution: Treaties, Non-Self-Execution, and the Original Understanding, 99 COLUM. L. REV. 1955 (1999).
} 
suggested exactly this process for pulling out of treaties: "[I]t will not be disputed that they who make treaties, may alter or cancel them: but still let us not forget, that treaties are made not by one only of the contracting parties, but by both; and consequently, that as the consent of both was essential to their formation at first, so must it ever afterwards be to alter or cancel them."137

But American practice has never followed this formalist approach to the repeal of treaties. Congress terminated the 1778 Alliance with France when it authorized the Quasi-War in $1798 .^{138}$ While President Adams signed the legislation, the process did not mirror the treaty process, as it included the House, did not require a supermajority of the Senate, and certainly did not seek France's approval. Presidents have long terminated treaties as well, most recently in 2002 when President George W. Bush withdrew from the Anti-Ballistic Missile Treaty with the Soviet Union. ${ }^{139}$ Summarizing presidential practice, Louis Henkin observed that "it is apparently accepted that the President has authority under the Constitution to denounce or otherwise terminate a treaty, whether such action on behalf of the United States is permissible under international law or would put the United States in violation." 140 In Goldwater $v$. Carter, a four-justice plurality of the Supreme Court agreed with a majority of the U.S. Court of Appeals for the D.C. Circuit that the President retains the traditional executive authority to unilaterally terminate treaties. ${ }^{141}$ Presidents and Senates cannot bind future Presidents to treaties, just as they cannot prevent future Presidents from removing executive branch officials.

Although the power to unilaterally abrogate a treaty flows from a grant of constitutional authority to the President to manage foreign relations, Congress may also enact laws that end a treaty or override its provisions. The fact that Congress has means of revoking a treaty (just as it may revoke a national monument) does not mean the President cannot do so on his own.

Finally, Congress is also constitutionally prohibited from delegating a statutory power to the President and then micromanaging the discretion granted. ${ }^{142}$ Thus, an attempt by Congress, in the original grant of power, to prevent later Presidents from using the delegated authority of the Antiquities Act to reverse an earlier monument designation (such as to privilege initial exercises

137. THE FEDERALIST No. 64, at 336 (John Jay) (Clinton Rossiter ed., 1961).

138. An Act to Declare the Treaties Heretofore Concluded with France, No Longer Obligatory on the United States, 1 Stat. 578 (July 7, 1798).

139. For a discussion of the ABM Treaty, see John Yoo, Politics as Law: The AntiBallistic Missile Treaty, the Separation of Powers, and Treaty Interpretation, 89 CAL. L. REV. 851 (2001). (2d ed. 1996).

140. LOUIS HENKIN, FOREIGN AFFaIRS AND THE UNITED STATES CONSTITUTION 214

141. See Goldwater v. Carter, 617 F.2d 697 (D.C. Cir.), vacated by Goldwater v. Carter, 444 U.S. 996 (1979); see also Kucinich v. Bush, 236 F. Supp. 2d 1 (D.D.C. 2002). For a summary of the academic discussion on treaty interpretation and termination, see John Yoo, The False Sirens of Delegation: Treaty Interpretation and Separation of Powers, 90 CAL. L. REV. 1305 (2002).

142. See Immigration Naturalization Serv. v. Chadha, 462 U.S. 919 (1983). 
of authority over later ones), would raise serious constitutional questions. ${ }^{143}$ Such logic would mean that Congress could pass laws preventing Presidents from ever removing a cabinet officer or terminating a treaty-indeed, their logic would imply that no one could remove an executive branch officer and treaties would be permanent.

Even if a strong presumption did not exist in administrative and other areas of federal law that the grant of a power includes the power to rescind prior executive actions, and even if it was unclear what Congress intended in the Antiquities Act, the courts should avoid a constitutional question by construing the Act to allow revocation. ${ }^{144}$ The courts should require a clear statement that Congress intends to deny a future President the power to revoke earlier designations before it decides whether an attempted one-way ratchet that binds his execution of the Act is constitutional. The constitutional avoidance canon is unnecessary, however: (a) in the absence of any authority that congressional silence implies that the revocation power does not exist, and (b) the existence of many counterexamples of that give rise to the opposite presumption.

\section{Procedures to Create, Modify, or Revoke National Monuments}

The Administrative Procedure Act's requirements governing agency action do not apply to actions by the President or the Executive Office of the President, even when a covered agency makes a recommendation to the President prior to his action. ${ }^{145}$ As explained below, the Antiquities Act alone defines the process to create, modify, or revoke a national monument, supplemented by executive practice concerning the issuance of presidential directives. There are no published court decisions or public opinions from the U.S. Attorney General or Office of Legal Counsel (OLC) governing the process of declaring or altering a national monument, ${ }^{146}$ but the Act's text and executive practice provide some guidance.

The Antiquities Act imposes few procedural requirements to create a national monument, essentially only that the President do so in a "public proclamation." 147 A procedure similar to that used to create a monument has been

143. If Congress follows the constitutional procedures to enact a new statute, it is free to codify a particular presidential action or change the underlying authority.

144. See Bond v. United States, 134 S. Ct. 2077 (2014), where the Court interpreted the implementing legislation to the Chemical Weapons Convention not to cover the mildly tortious conduct of a jealous wife to avoid serious federalism issue.

145. Franklin v. Massachusetts, 505 U.S. 788, 800-01 (1992) (holding that the President's actions are not reviewable under the APA, even when a covered executive agency is involved in recommending his action).

146. Although OLC has not opined on the process to create or modify a national monument, it has addressed legal issues relating to the management of national monuments, including the transfer of management responsibility from one federal agency or bureau to another or the import of other laws on lands designated national monuments.

147. See Antiquities Act of 1906, Pub. L. 59-209, 34 Stat. 225, $\$ 2$ (1906) (codified at 54 U.S.C. $\$ \S 320301-03(2018)$ ). 
employed at least eighteen times to modify monument boundaries, and there is no reason to doubt it would be equally effective to revoke one, assuming, as we do, that such power exists.

The relevant portion of the Antiquities Act's text provides only that the President

\begin{abstract}
declare by public proclamation historic landmarks, historic and prehistoric structures, and other objects of historic or scientific interest that are situated upon the lands owned or controlled by the Government of the United States to be national monuments, and may reserve as part thereof parcels of land, the limits of which in all cases shall be confined to the smallest area compatible with the proper care and maintenance of the objects to be protected. ${ }^{148}$
\end{abstract}

Thus, the President must act through a "public proclamation," though the form of the proclamation is not circumscribed in any detail. The President must comply with the substantive requirements of the Act, but few, if any, of the conditions need to be set forth in the public proclamation. For example, the land reserved for the monument must be owned or controlled by the United States, but satisfaction of that requirement likely need not be set forth in the proclamation. The President must also ensure that the land reservation be for a protective purpose consistent with the Act and that the area reserved is "confined to the smallest area compatible with the proper care and maintenance of the objects to be protected," although the reasoning behind those determinations likely need not be included in the proclamation.

Presidential proclamations, executive orders, and related presidential directives have been in use since the administration of George Washington, but there is no statute or constitutional provision that dictates their form. ${ }^{149}$ Other statutes granting the President a new power may be specific as to the findings or determinations that must be included in a public proclamation or executive order, but such was not the case in the Antiquities Act.

Nevertheless, some general executive practice principles may be relevant to the legal issues discussed in this essay as well as some that are specific to the issuance of national monument proclamations. Since the creation of the Office of Legal Counsel (OLC) in the U.S. Department of Justice in the mid-20th century, it assumed the duty previously exercised by other officials of reviewing almost all draft presidential directives with regard to both their form and legality. ${ }^{150}$ We believe the review by OLC's professional staff is generally more thorough than that by some officials in earlier eras.

148. Id.

149. See generally Todd F. Gaziano, The Use and Abuse of Executive Orders and Other Presidential Directives, 5 TEX. REV. L. \& POL. 267 (2001) (describing the history, uses, and law relating to executive orders, proclamations, and other presidential directives).

150. Both authors served in OLC, collectively spanning four presidential administrations. Gaziano served briefly in the Regan administration and later in the George H.W. Bush and Clinton administrations, where he became a senior advisor in the review of draft presidential 
Unless the normal OLC review was bypassed, and there is no reason to think it was, OLC would have reviewed the two proclamations President Trump issued on December 4, 2017 significantly shrinking Bears Ears and Grand Staircase-Escalante National Monuments. As such, OLC would have considered the significant reductions and opined that the proclamations were legal in a traditional letter to the President transmitting the draft directives. ${ }^{151}$ It is also possible OLC wrote a longer unpublished (and thus confidential) opinion or memorandum on the subject. Such unpublished opinions are constitutionally protected from discovery in most proceedings, but as interesting as OLC's reasoning may be, one conclusion can be deduced from President Trump's actions: to the extent that Attorney General Cummings's 1938 opinion also precludes a significant reduction of a national monument, and the critics of presidential power so argue, as discussed in the next section, Cummings's opinion has since been overruled. ${ }^{152}$

The specific practice regarding national monument proclamations is contained in the more than 200 such proclamations that have been issued to create 117 national monuments and to adjust their boundaries. The next section describes how significant some of the boundary adjustments have been (including an $89 \%$ reduction to one early monument), but our focus is the general nature of such proclamations here. A selective survey suggests that the proclamations vary significantly in the relative formality and the level of detail provided, but more recent proclamations seem to provide more detailed justification for the creation or alteration of a monument. ${ }^{153}$

Regarding the level of public input and participation prior to a presidential decision to create, modify, or revoke a national monument, none is required by the Antiquities Act or any other law. It is prudent for any administration to provide a transparent and inclusive process, especially for the creation, revocation, or significant modification of a large national monument. Members of Congress have sought to amend the Antiquities Act to require such input, especially from local government entities that might be affected. ${ }^{154}$. But the irony of recent complaints that the process in the current administration lacked

directives. Yoo was a Deputy Assistant Attorney General at OLC during George W. Bush's administration.

151. The other possibilities are that the OLC was not consulted, which would be quite unusual, or that the OLC advised that the proclamations were illegal and the President overruled that opinion, which we are unaware has ever happened.

152. The legal advice function was conferred originally on the Attorney General, 28 U.S.C. $\S \S 511-13$ (2012), and delegated by him to OLC, see $i d$. $\S 510$ (allowing such delegation); see also 28 C.F.R. $\S 0.25$ (2017) (making such delegation). Pursuant to that delegation, OLC opinions have the same force in the executive branch as Attorney General opinions, which OLC still occasionally drafts for the Attorney General.

153. Compare, e.g., Proclamation No. 873, 36 Stat. 2491 (Mar. 20, 1909), with Proclamation No. 9558, 82 Fed. Reg. 1,139 (Dec. 28, 2016); Proclamation No. 9681,82 Fed. Reg. 58,081 (Dec. 4, 2017).

(2017).

154. See, e.g., Improved National Monument Designation Act, S. 33, 115th Cong. 
transparency is that the modification of Bears Ears National Monument was more public and inclusive in many respects than the process President Obama used to create it. ${ }^{155}$

\section{A Limited Power to Revoke Certain National Monuments or Declare Others Invalid}

Even if every monument designation cannot be revoked as a matter of presidential discretion, authority should still exist to abolish or significantly reduce some designations based on an earlier factual error, changed circumstances, or an original statutory violation. In short, three determinations, two factual and one legal, may provide strong grounds for certain monument revocations or invalidations.

\section{A. New Factual Determinations}

First, if the President concludes that the original designation was mistaken, perhaps because of an archeological fraud, historical error, or improved or updated scientific analysis, the predicate for original designation would be undermined. It would be hard to argue that Congress intended that every curiosity deemed scientifically interesting to a President 100 years ago (the once popular but now discredited and racist branch of human craniology/phrenology comes to mind; the Piltdown Man hoax is another) forever must remain a valid source of scientific interest and protection-absent the hurdle of enacting legislation that corrects the error. It might be more subjective for a President to determine that a geological monument designation (assuming any are legal) thought to be rare and scientifically interesting by an earlier President is not all that worthy of protection as a monument, but limiting such reevaluation would elevate certain determinations (or privilege geological claims) over others in a manner that would be hard to logically sustain.

Second, as explained above, the Antiquities Act also was intended to provide authority to preserve artifacts that might otherwise be looted. Even assuming the original designation was proper, if the relevant artifacts were excavated and removed, and they are now on display in a museum off-site, how can it be said that the reserved parcels are currently the "smallest areas compatible with the proper care and management of the objects to be protected"? If any of these changes of fact or scientific interest justify revocation, then the general argument against revocation would be on shaky grounds, and

155. See Darryl Fears \& Juliet Eilperin, Interior Secretary Recommends Trump Consider Scaling Back Bears Ears National Monument, WASH. POST (June 12, 2017), https://www.washingtonpost.com/news/energy-environment/wp/2017/06/12/interior-secretaryrecommends-delaying-a-final-decision-on-changing-bears-ears-national-monument [https://perma.cc /V3MQ-WEP3]. 
discretionary revocations at will would be a more plausible interpretation of the Act.

\section{B. Problems of Size}

A presidential determination that an original designation was illegally or inappropriately large is a special case. It may provide a sound predicate for declaring a designation to be invalid or for significantly reducing the monument's size. The President might be presented with an issue analogous to a severability determination. If there is no reasonable way to reduce a reservation's size and maintain a meaningful monument, rescinding or declaring invalidity may be more appropriate. A review of controversies over the size of national monuments highlights three distinct periods of use and abuse, the last of which contains the most breathtakingly large monument designations.

Between 1906 and 1943, most monument reservations were smaller than 5,000 acres, and many of them actually protected antiquities. Yet there also were several large monument reservations or expansions during that period, mostly for scenic or geological formations. President Franklin D. Roosevelt's designation of Jackson Hole National Monument in 1943 was the catalyst for two reforms, only one of which was made permanent. Wyoming congressmen were strongly opposed to the 210,950 -acre monument and reservation and secured a bill to overturn it, but President Roosevelt vetoed it. ${ }^{156}$ In 1950 , Congress made Grand Teton National Park out of most of the land from the Jackson Hole monument and added the southern portion of the former monument to the National Elk Refuge. ${ }^{157}$ That law also amended the Antiquities Act, forbidding further use of it to expand or establish a national monument in Wyoming without express congressional authorization. ${ }^{158}$ The proviso enacted in 1950 does not prohibit the President from reducing the size of the monument reservation in Wyoming.

For the next thirty-five years, Presidents remained moderate in their use of the Antiquities Act. Except for a couple of proclamations by President Lyndon B. Johnson, the period between 1943 and 1978 contained no especially vast monument reservations, and some Presidents even reduced the size of older monuments. President Dwight D. Eisenhower's combined proclamations under the Act caused a net reduction in total acreage devoted to national monuments. President Richard M. Nixon issued no Antiquities Act proclamations whatsoever.

156. Hal K. Rothman, America's National Monuments: The Politics of Preservation, Chapter 11: The ANTIQUities ACt AND the MODERn PARK System (1994).

157. Pub. L. No. 105-81, 64 Stat. 849 (1950) (codified at 54 U.S.C. § 320201(d) (2018)).

158. Id. ("No extension or establishment of national monuments in Wyoming may be undertaken except by express authorization of Congress."). 
In 1976, Congress enacted the Federal Land Policy and Management Act (FLPMA), which expressly limits a Secretary of Interior from permanently withdrawing or modifying more than 5,000 acres of federal land without congressional approval. ${ }^{159}$ It provides:

The Secretary shall not make, modify, or revoke any withdrawal created by Act of Congress; make a withdrawal which can be made only by Act of Congress; modify or revoke any withdrawal creating national monuments under [the Antiquities Act]; or modify, or revoke any withdrawal which added lands to the National Wildlife Refuge System prior to October 21, 1976, or which thereafter adds lands to that System under the terms of this Act. ${ }^{160}$

Some scholars, including Squillace and his co-authors, have suggested that this provision prohibits revocation or modification of monuments by all executive branch officials, including the President. ${ }^{161}$ They primarily rely on a House Committee report that states that FLPMA "would specifically reserve to the Congress the authority to modify and revoke withdrawals for national monuments created under the Antiquities Act."162

The lone snippet of an otherwise ambiguous legislative history report of one House is an especially weak thread on which to hang such a crucial argument. For one, even if the legislative history were clear regarding the President's lack of authority to revoke national monuments and represented the actual view of both Houses of Congress, it is not the law. ${ }^{163}$ Congress neither amended the Antiquities Act in 1976, nor changed the President's authority to revoke a national monument in the text of the FLPMA. ${ }^{164}$

The FLPMA's express limitation on the Secretary simply confirms the natural reading of the Antiquities Act, which grants authority to the President alone to specify the parcels of land withdrawn for any monument created pursuant to the Act. It should not be read to raise doubts about the President's authority to modify or revoke national monuments. The text creates no ambiguity or inference that Congress modified the President's authority in the Antiquities Act. The opposite reading of the text is much stronger, i.e., that Congress knew how to write express limitations and that it would have listed the President if its restriction on the Secretary of Interior's power was intended to bind the

\footnotetext{
159. Pub. L. No. $94-579,90$ Stat. 2743 (1976) (codified as amended at 43 U.S.C. $\$ 1701$ et seq. (2018)).

160. Id. $\S 204(\mathrm{j})$.

161. See, e.g., WYATT, supra note 85, at 6; PAMELA BALDWIN, CONG. RESEARCH SERV., RS20647, Authoruty OF A PRESIDENT to MODIFy OR Eliminate a NATIONAL MONUMENT (2002); Squillace et al., supra note 11, at 59-64.

162. H.R. REP. NO. 94-1163, at 9 (1976).

163. See SCALIA \& GARNER, supra note 115 , at 56.

164. Federal Land Policy and Management Act $\$ 204(j), 43$ U.S.C. $\$ 1714(j)$ (2012).
} 
President. ${ }^{165}$ The legislative history cited for the contrary view is itself ambiguous, but should not be consulted when the statutory text is clear.

Perhaps the House Report author would have liked to deny the President this power, or perhaps it was written without thinking about the President's authority, but it did not make it into the law that Congress enacted. Courts have been clear that legislative history cannot change unambiguous text and that legislative history from a later Congress is not a useful guide for legislation passed by an earlier one. ${ }^{166}$ Furthermore, an implied repeal of an existing statute or the President's authority under it, which is all this argument could be, is strongly disfavored. ${ }^{167}$ As with clear statement rules in other areas, we should expect Congress to risk a severe intrusion into the President's constitutional and statutory authority in plain and unmistakable text.

These principles sink the argument relying on the FLPMA House Report. FLPMA is clear that the limitation only applies to the Secretary, not the President. Just as the House Report cannot change the text of FLPMA, it cannot change the meaning of the Antiquities Act. Simply put, the report-even if it accurately reflected the views of the entire House of Representatives in 1976is of no help in interpreting a statute enacted seventy years earlier. ${ }^{168}$

Unfortunately, the abuses under the Antiquities Act expanded significantly after 1978, especially by Presidents Carter, Clinton, George W. Bush, and Obama. Until Obama's last year in office, President Carter held the record for the most extensive monument reservations, with nine designations that were larger than a million acres and two larger than ten million acres. Carter's designation of more than fifty-six million acres of monument reservations in Alaska on a single day led to the most recent amendment to the Antiquities Act.

The Alaska National Interest Lands Conservation Act (ANILCA) was enacted by Congress and signed by President Carter on December 2, 1980, after his election loss to Reagan and the impending loss of Democratic Party control in the Senate. ${ }^{169}$ The ANILCA settled many long-standing issues and land disputes, and it made many Alaska-specific changes to laws governing federal land management, including requiring congressional approval for national

165. See WILLIAM N. ESKRIDGE JR., INTERPRETING LAW: A PRIMER ON HOW TO READ STATUTES AND THE CONSTITUTION 408 (2016) (noting that the Expressio Unius canon reaches this conclusion); accord Hinck v. United States, 550 U.S. 501 (2007). U.S. $280,298(2010)$.

166. See, e.g., Graham Cty. Soil \& Water Conservation Dist. v. U.S. ex rel. Wilson, 559

167. The Supreme Court has established a strong presumption against implied repeals. See, e.g., Powerex Corp. v. Reliant Energy Servs., Inc., 551 U.S. 224 (2007); see also Daniel B. Listwa, An "Unusual Jurisdictional Argument": The Codifier's Canon in Ayestas v. Davis, 35 YALE J. ON REG. BULL. 51 (2018) (offering discussion of a rare argument over the existence of an implied repeal).

168. ESKRIDGE, supra note 165 , at 425 ("Views of a subsequent Congress are a hazardous basis for interring the intent of an earlier one."); accord Bruesewitz v. Wyeth LLC, 562 U.S. 223 (2011).

169. Pub. L. No. 96-487, 94 Stat. 2371 (1980) (codified at 16 U.S.C. 410 hh-3233, and 43 U.S.C. 1602-1784 (2018)) 
monuments in Alaska larger than 5,000 acres. ${ }^{170}$ Whether this congressional reaction made an impression on them or for other reasons, Presidents Reagan and George H. W. Bush both issued no proclamations under the Antiquities Act.

Nevertheless, President Clinton broke new ground with the number of monument designations per term, ${ }^{171}$ many of which were larger than 100,000 acres and two of which were larger than one million acres. ${ }^{172} \mathrm{He}$ also proclaimed a questionable new type of monument on the high seas. President George W. Bush issued fewer than half as many monument designations as Clinton, and some were relatively small. Yet, President George W. Bush made a few large monument designations, including a questionable designation along the Pacific Ocean's Marianas Trench. ${ }^{173}$

President Barack Obama broke both Clinton's record number of monument proclamations per term and Carter's record for the total acres withdrawn. Among his thirty-four proclamations, ${ }^{174}$ Obama enlarged the Papahanaumokuakea Marine National Monument by approximately 283.4 million acres, ${ }^{175}$ enlarged the Pacific Remote Islands Marine National Monument by approximately 261.3

170. See 16 U.S.C. $\$ 3213$ (2018).

171. President Obama's thirty-four designations also overtook the previous record set by President Franklin Roosevelt, with thirty-two monument proclamations. See Juliet Eilperin \& Brady Dennis, Obama Names Five New National Monuments, Including Southern Civil Rights Sites, WASH. POST (Jan. 12, 2017), http://www.washingtonpost.com/national/health-science/obama-names-five-newnational-monuments-including-southern-civil-rights-sites/2017/01/12/7f5ce78c-d 907-11 e6-9a36-

1d296534b31e_story.html [http://perma.cc/X5ZK-HHUG]. All Presidents since 1906 have issued such proclamations except Presidents Nixon, Reagan, and George H. W. Bush. See National Monuments Designated by Presidents 1906-2009, NAT'L PARK SERV., http://www.nps.gov/parkhistory/hisnps NPSHistory/national_monuments.pdf [http://perma.cc/C5UM-6QXE]. According to the National Parks Conservation Association, 157 monuments have been created under the Antiquities Act. See Monuments Protected Under the Antiquities Act, NAT'L PARKS CONSERVATION ASS'N, http:// www.npca.org/resources/2658-monuments-protected-under-the-antiquities-act [http://perma.cc/Z2HHPB58]. A few have been abolished by Congress. See About 'Abolished' Monuments, NAT'L PARK SERV. (Mar. 15, 2016), http:/www.nps.gov/archeology/sites/antiquities/abolished.htm [http://perma.cc/V6UX6RRV]. And the land constituting Papago Saguaro National Monument was conveyed to the state of Arizona for public purposes. See An Act to Abolish the Papago Saguaro National Monument, 71 Pub. L. No. 92, 46 Stat. 142 (1930).

172. See Albert C. Lin, Clinton's National Monuments: A Democrat's Undemocratic Acts, 29 ECOLOGY L. Q. 707, 718-19 (2002).

173. See Bryan Walsh, President Bush's Last Act of Greenness, Time (Jan. 6, 2009), http://content time.com/time/health/article/0,8599,1869917,00.html [http://perma.cc/HWV5-PWJM] (noting that President Bush will have "protected more of the ocean than anyone else in the world").

174. See Eilperin \& Dennis, supra note 171; Dana Varinsky, Here's Every Piece of Land Obama Has Put Under Protection During His Presidency, BUS. INSIDER (Jan. 16, 2017, 12:03 PM), http://www.businessinsider.com/every-piece-of-land-obama-has-protected-2017-1/\#cascade-siskiyounational-monument-1 [http://perma.cc/HU6S-7J3U].

175. President Announces Expansion of Papahānaumokuākea, PAPAHANAUMOKUAKEA MARINE NAT'L MONUMENT (Jan. 12, 2017), http://www.papahanaumokuakea .gov/news/expansion_announcement.html [http://perma.cc/6DQG-HVWW]. 
million acres, ${ }^{176}$ and created the Northeast Canyons and Seamounts Marine National Monument, which covers approximately 3,144,320 acres. ${ }^{177}$

Several of President Obama's proclamations occurred despite strong congressional opposition and undermined pending legislation. Two examples are the 1.35 million-acre Bears Ears National Monument in southern Utah and the 300,000 -acre Gold Butte National Monument in Nevada. Both designations were opposed by state officials and GOP congressional leaders, including the unanimous congressional delegation from Utah, which was willing to compromise on a smaller monument in Utah that permitted reasonable public uses of the area. The protective impact of the Bears Ears National Monument is particularly dubious since it is supposed to protect isolated Native American sites. It is unclear, for example, how the agency officials will protect those sites any differently after the monument designation than they might have before.

A designation smaller than 5,000 acres may still be too large (relative to some objects being protected) or politically abusive if the designation is for a questionable purpose, for example, to interfere with congressional deliberations over a compromise land-use arrangement or to regulate fishing that is not otherwise authorized. But reservations larger than 5,000 acres merit special review out of respect for Congress' traditional authority to establish federal land policy, especially if there was no "emergency" necessitating the monument designation without congressional action or if congressional leaders had expressed serious opposition to the monument designation.

If a President makes a credible determination, based on the facts and a reasonable interpretation of the act, that some former monuments are illegally large relative to the original "object" supposedly being protected, he could declare that the initial designation was void, especially if there is no easy way to make it lawful by severing discrete parcels of land. That is distinct from his power to "revoke" those he thinks were originally lawful, and it would stem from his constitutional authority to take care that the laws are faithfully executed. Even so, a President trying to insulate such a decision could invoke both his constitutional authority to declare the prior designation void and his authority under the Act to revoke the designation if it were legal. If he uses both sources of authority, he could issue a proclamation to exercise his authority under the Antiquities Act.

176. Bryan C. Howard, US Creates Largest Protected Area in the World, $3 x$ Larger than California, NAT'L GEOGRAPHIC (Sept. 26, 2014), http://news.nationalgeographic.com/news/2014/09 /140924-pacific-remote-islands-marine-monument-expansion-conservation [http://perma.cc/8YS99HW5].

177. See Press Release, White House Office of the Press Sec'y, Fact Sheet: President Obama to Continue Global Leadership in Combatting Climate Change and Protecting Our Ocean by Creating the First Marine National Monument in the Atlantic Ocean (Sept. 15, 2016), http://obamawhitehouse.archives.gov/the-press-office/2016/09/15/fact-sheet-president-obama-continueglobal-leadership-combatting-climate [http://perma.cc/3LLC-SWXE]; see also infra Section III.C (discussing the unique problems with monument designations of submerged land under the high seas and a citation to a recent lawsuit challenging the legality of the Northeast Canyons and Seamounts Marine National Monument). 


\section{Special Questions Regarding Marine Monument Designations}

The Supreme Court has upheld or discussed the application of the Antiquities Act to the submerged lands of two different monuments along the coast and inland waterways. ${ }^{178}$ Still, purported monuments on the high seas present distinct legal problems. Such marine monument designations a hundred plus miles from American shores or territorial waters are a recent and highly questionable development.

The high-sea designations by Presidents Clinton, George W. Bush, and Obama are easily distinguishable from the inland waterway and territorial sea designations, except that all involve salty water. The most recent high-sea monument was President Obama's designation of the Northeast Canyons and Seamounts Marine National Monument, 130 to 200 miles off Cape Cod. This approximately 3.14 million-acre area is in the United States' Exclusive Economic Zone (EEZ), but America does not own the seabed there or the ocean above it. In March 2017, the Pacific Legal Foundation filed suit on behalf of a coalition of New England fishing organizations challenging the legality of the most recent marine monument, which is the first lawsuit of its kind. ${ }^{179}$

The federal district court stayed the fishermen's suit on the repeated representations by the Justice Department in 2017 that President Trump might take action soon to reduce or revoke the monument, ${ }^{180}$ but the court finally ordered a responsive pleading on March 15, 2018. The administration subsequently filed motions to dismiss the suit on April 16, 2018, guaranteeing continued litigation seeking the monument's invalidation or, conversely, new litigation seeking its restoration if the President does revoke it. ${ }^{181}$

There are several problems with the designation of marine monuments far from shore under the Antiquities Act. The most important is that the United States does not own the seabed or the oceans beyond its territorial waters and it cannot assert the type of control over either that is required by the Antiquities Act. ${ }^{182}$ The modern EEZ is not only vastly wider than the "territorial waters" of 1906 but also a qualitatively different type of property interest than the United States may have had in $1906 .{ }^{183}$ The United States has a sovereign interest in and

178. See Alaska v. United States, 545 U.S. 75 (2005); United States v. California, 436

179. Complaint, Mass. Lobstermen's Ass'n v. Ross., No. 1:17-cv-00406 (D.D.C. Mar. 7, 2017), 2017 WL 897829. The authors each have affiliations with Pacific Legal Foundation. Todd Gaziano is one of the attorneys for the plaintiffs in the case. John Yoo joined the board of Pacific Legal Foundation in early 2017.

180. See, e.g., id. (granting a stay and extensions in 2017 based on the DOJ's representation that the monument at issue might be affected by presidential action).

181. See, id., for the most recent docket entries and pleadings in the case.

182. See Antiquities Act of 1906, Pub. L. 59-209, 34 Stat. 225 (1906) (codified at 54 U.S.C. $\S \S 320301-03$ (2018)).

183. See Joseph Briggett, Comment, An Ocean of Executive Authority: Courts Should Limit the President's Antiquities Act Power To Designate Monuments in the Outer Continental Shelf, 22 TULANE ENVTL. L.J. 403 (2009). 
almost complete control over the submerged land near its coast and its territorial waters (then three miles from the coast and now twelve miles), which justifies tight military and other controls; it still does not have such a sovereign control over the area beyond its territorial waters. ${ }^{184}$ Even current domestic and international law permits only limited regulation of the marine and wind resources in the EEZ outside our territorial waters, and thus, it does not constitute the type of federal government "control" of "land" required under the Antiquities Act.

In Treasure Salvors, Inc. v. Unidentified Wrecked and Abandoned Sailing Vessel, the Fifth Circuit held that the Antiquities Act does not extend beyond the territorial sea. ${ }^{185}$ Although the Fifth Circuit acknowledged that the federal government's role in regulating beyond the territorial seas had expanded since 1906, especially through the adoption of the Outer Continental Shelf Lands Act, ${ }^{186}$ none of that conveyed the degree of control that the federal government enjoyed on federally owned lands or federally controlled territories in $1906 .^{187}$

When President Clinton proposed to designate the first marine monument beyond American territorial waters, the Departments of Interior and Commerce submitted a joint memorandum to the Justice Department asserting that the EEZ is not "owned or controlled by the Federal Government." "188 The OLC ultimately disagreed but acknowledged that it was a "closer question" than earlier disputes over the President's designation authority. ${ }^{189}$

The OLC opinion suffers from several critical flaws, and as such, should be reversed by the DOJ and disregarded by the courts. It argues that the EEZ is sufficiently controlled by the federal government because recent Presidents have consistently asserted some regulatory authority over the area, and the United States has greater regulatory authority than any foreign government. ${ }^{190}$ Of course, the same is true of many areas that are unquestionably not "owned or controlled by the Federal Government" within the meaning of the Act, such as private land within the United States, which is subject to a greater federal regulation than the EEC but categorically excluded from land that can be made a national monument. ${ }^{191}$

INST. 1987).

184. See RESTATEMENT (THIRD) OF FOREIGN RELATIONS LAW $\$ 514 \mathrm{cmt}$. c (AM. LAW

185. 569 F.2d 330 (5th Cir. 1978).

186. Pub. L. No. 83-212, 67 Stat. 462 (codified at 43 U.S.C. $\S 1331$ et seq. (2018)).

187. See Treasure Salvors, 569 F.2d at 339-40.

188 Dep't of Interior and Dep't of Com., Memorandum Re: Request for Opinion Regarding Administration of Coral Reef Resources in the Northwest Hawaiian Islands (June 30, 2000).

189. See Administration of Coral Reef Resources in the Northwest Hawaiian Islands, 24 Op. Att'y Gen. 183 (2000) [hereinafter Randolph Memo].

190. See id. at 196.

191. The Antiquities Act states that the President can receive privately owned lands and include them in a monument only through the owner's voluntary relinquishment of them. See 54 U.S.C. $\S 320301$ (2018). The Randolph Memo also asserts that the EEZ is sufficiently controlled by the federal government because it has the authority to protect threatened or endangered species found there. Randolph Memo, supra note 189 , at 197 . Yet the same could be said of any privately-owned land under the 
Finally, even if the Antiquities Act does allow monument designations in international submerged lands in the United States' EEZ, such designations might be valid only for the seabed itself and for the purpose of seabed protection. If so, that would provide additional authority to revoke designations that are primarily designed to protect sea life in international waters and remove other restrictions in ocean habitat, even if they are above seabed features that might be the subject of protection. To be clear, other authority exists to regulate fishing and other activity in the oceans, but it is questionable whether the Antiquities Act provides such authority.

The Act's text provides strong support for limiting monuments to landmarks and objects on parcels "of land." authority for monument designations of only "landmarks, historic and prehistoric structures, and other objects of historic or scientific interest that are situated upon the land," and when such monuments are designated, the President may then "reserve as part thereof parcels of land" for protection. ${ }^{193}$ There may be some ancillary power to regulate the air above a monument or some activity in the territorial sea above a marine monument, but it is doubtful that the distant ocean and its living denizens can be designated as part of the monument. It is equally doubtful that a reservation of the seabed can encompass the water column as a matter of presidential discretion under the Antiquities Act.

In Cappaert, the Supreme Court upheld some authority to regulate the immediate watershed outside a monument if that is necessary to protect geologic structures and endangered wildlife in the monument grounds, but its holding was based on other federal law governing reserved water rights on land where water is scarce. ${ }^{194}$ That source of law doesn't apply to an ocean. The Court did mention the endangered fish that swim in the unmoving pool of the monument at issue, but that reference is not necessary to its holding that appurtenant water outside the monument was reserved pursuant to other federal law. The facts of that case are distinguishable in other ways from the unbounded ocean and the unthreatened fish, mammals, and other sea creatures that swim in and out of it. For many reasons, monuments on the high seas are not authorized by the Antiquities Act of 1906.

Endangered Species Act. Finally, the limited type of regulation allowed in the EEC conflicts with the extensive control required by the Antiquities Act. The OLC opinion cannot be squared with any of these principles.

192. See Antiquities Act of 1906, Pub. L. 59-209, 34 Stat. 225, § 2 (1906) (codified at 54 U.S.C. $\$ \S 320301-03(2018)$ ).

193. Id. (emphasis added).

194. See Cappaert v. United States, 426 U.S. 128 (1976) (holding that "when the Federal Government withdraws its land from the public domain and reserves it for a federal purpose, the Government, by implication, reserves appurtenant water then unappropriated to the extent needed to accomplish the purpose of the reservation"). 


\section{The Power to Reduce the Scope of a Reservation in a Monument Designation}

Almost all commentators, including past opinions from the attorney general and the Solicitor of Interior, agree that monument boundary adjustments are permissible. ${ }^{195}$ Environmentalists often seek large expansions of existing monuments. As a result, several Presidents have added vast additional reservations to existing national monuments, including three by President Obama that added millions of acres. Many Presidents have made other boundary adjustments, including some modest to large reductions, and the Supreme Court has cited some of these changes in describing the monuments at issue, implicitly assuming they were valid. ${ }^{196}$

If large additions of land have been deemed necessary to protect certain objects, it is doubtful the President could not determine that some large reductions are reasonable or necessary to satisfy the "smallest area" requirement of the Act. Modern technology might even help justify a reduction, for example, if smaller boundaries may now be more effectively monitored and protected.

Yet several commentators claim that the question of whether the President could affect significant reductions remains open. ${ }^{197}$ No court has ruled on the scope of downward boundary adjustments. Several commenters assert that judicial authority is absent because no President has attempted a significant reduction in the land reserved for a monument. This assertion is not true. According to the National Park Service:

- President Eisenhower reduced the reservation for the Great Sand Dunes National Monument by twenty-five percent (he reduced the original 35,528 -acre monument by a net 8,920 acres). ${ }^{198}$

- President Truman diminished the reservation for Santa Rosa Island National Monument by almost half. (The original 9,500-acre reservation by Franklin D. Roosevelt was diminished by 4,700 acres.) ${ }^{199}$

- Presidents Taft, Wilson, and Coolidge collectively reduced the reservation for Mount Olympus by almost half, the largest by President Wilson in 1915 (cutting 313,280 acres from the original 639,200-acre monument). ${ }^{200}$

supra note 13

195. See National Monuments, 60 Interior Dec. 9 (1947), citing Cummings Opinion,

196. See Alaska v. United States, 545 U.S. 75 (2005).

197. See, e.g., Ranchod, supra note 46 , at 554.

198. Proclamation No. 3138, 21 Fed. Reg. 4035, 4035 (June 13, 1956); see also Michael M. Geary, SEA of SAND: A History of the Great SAND DUNES National Park and PRESERVE (2016) (discussing this reduction).

199. Proclamation No. 2659, 59 Stat. 877 (Aug. 13, 1945).

200. Gail H. E. Evans, Historic Resource Study, Appendix A: A Chronology of the Public Domain, NAT'L PARK SERV. (1983), http://www.nps.gov/parkhistory/online_books/olym/hrs /appa.htm [http://perma.cc/UEX8-XP8C]. 
- The largest percentage reduction was by President Taft in 1912 to his own prior reservation in 1909 for the Navajo National Monument. (His elimination of 320 acres from the original 360-acre reservation was an eighty-nine percent reduction. $)^{201}$

There are many other reductions or adjustments to monument boundaries, but the above reductions are significant by any measure. Thus, what seems likely is that no one thought it reasonable or possible to challenge these large monument reductions prior to 2017.

Scholars who claim that Presidents cannot order significant reductions misread the Act's purposes or rely on policy arguments instead of the statutory text. They often build upon the premise that authority to repeal or rescind a prior designation does not exist, including an uncritical reliance on Attorney General Cummings's questionable 1938 opinion. Under this reading of the Antiquities Act, monuments may be significantly enlarged by later Presidents but never significantly reduced absent an act of Congress.

For many of the same reasons that we reject a limitation on the President's revocation power, we also question limitations on his power to substantially reduce the size of existing monument reservations. Moreover, there are additional reasons why the President has broad authority to alter the parcels of land reserved under existing monument designations, including logical inferences from textual provisions and the varied reasons prior Presidents have given for boundary reductions.

One textual signal in support of boundary adjustments is that the Antiquities Act requires reservations to be "in all cases ... confined to the smallest area compatible with the proper care and management of the objects to be protected."202 There is no temporal limit to this requirement. Some presidential proclamations adjusting the boundaries of existing monuments recognize a continuing duty to review and comply with this command. Even if boundary adjustments to date had all been somewhat minor, which is not the case, it is hard to read into the text a limiting principle that allows large additions but not large reductions.

Another textual hook is the discretionary nature of the President's authority under the Antiquities Act. The relevant language in Section 2 states that it is "in his discretion" whether to declare the national monument. It then states that he "may reserve as part thereof parcels of land" to protect the objects at issue. ${ }^{203}$ The parcels must, as noted above, be confined to the smallest area compatible with the protective purpose, but it is still up to the President's discretion which precise parcels to designate. Apart from reducing the overall size, the next

201. Hal K. Rothman, Navajo National Monument: A Place and Its People, Chapter 2: Founding Navajo National Monument, NAT'L PARK SERV. (1991), https://www.nps.gov/parkhistory /online_books/nava/adhi/adhi2e.htm [http://perma.cc/T76M-MJ2L].

202. Antiquities Act of 1906, Pub. L. 59-209, 34 Stat. 225, § 2 (1906) (codified at 54 U.S.C. $\$ \S 320301-03(2018)$ ).

203. Id. (emphasis added). 
President may determine that a given monument with a patchwork of private inholdings is better protected by concentrating the monument within the federal land that the government owns and controls. ${ }^{204}$ There is nothing in the Act that privileges the original designation and regulations over a later presidential determination.

There are more fundamental questions about how best to manage and protect federal property near national monuments with available resources. The belief that increasing federal regulation is always the best means of protecting something is more ideologically than empirically based, especially when it excludes all other options. Cooperation with state authorities and private property owners who own adjoining land can promote superior land-use decisions, including better protections for such properties. Such consultation and multiparty agreements tend to increase support for the resulting decisions and increase fundamental fairness, since some prior designations have walled in private lands and restricted the reasonable use of such private property.

The evidence surrounding many recent monument designations also suggests that some of the largest geological and scenic monuments were not motivated exclusively or even primarily by a desire to protect an "object" of historic or scientific interest as much as to lock up natural resources from development and use-regardless of how limited or temporary the surface disturbances would be. Such actions not only create economic hardship for local communities and injustice to those who may have reasonably depended on the timber, grazing, or mineral resources, but they may actually be counterproductive to the ecological and environmental interests that past Presidents claimed to protect. For example, prohibiting fishing in vast grounds in the Atlantic or Pacific Oceans where fishermen have engaged in sustainable practices forces more concentrated activity in other areas that may trigger unsustainable impacts.

Such large monument reserves also contribute to an estimated $\$ 13.5$ to $\$ 20$ billion maintenance backlog on Department of Interior land-management responsibilities $^{205}$ - and deny the federal government any reasonable return on land-use fees and leases. A more careful accounting of federal land policy might lead a President to conclude that some vast monument reserves, under the Antiquities Act and other acts, diffuse attention and resources from higher priorities and contribute to environmental degradation, soil erosion, and other forms of mismanagement of federal property. Apart from all that, increasing public use of vast tracts of federal land should be sufficient grounds for reducing certain prior monument reservations. The facts that underlie one Supreme Court

204. See, e.g., Wilkerson v. Dep't of the Interior, 634 F. Supp. 1265, $1280-81$ (D. Colo. 1986) (holding that the United States could not completely restrict travel on a preexisting right of way through a national monument).

205. Anu K. Mittal and Frank Rusco, Dirs., Nat. Res. and Env't, Testimony Before the Subcommittee on Interior, Environment, and Related Agencies, http://www.gao.gov/assets/130 /125531.pdf [http://perma.cc/UZ9N-5MNG]. 
case may prove instructive in defining possible grounds for monument reductions.

In Alaska v. United States, the Supreme Court affirmed its special master's recommendation regarding the federal versus state ownership of certain submerged lands underwater near Alaska's southeast coast. ${ }^{206}$ Some of the land in dispute was under Glacier Bay, which is now a national park. Glacier Bay was first reserved as a national monument by President Coolidge in 1925 and later enlarged by President Franklin D. Roosevelt's in 1939, both pursuant to the Antiquities Act. In describing the relevant lands in question, the Court also noted that President Eisenhower "slightly alter[ed]" the monument's boundaries in $1955 .^{207}$

The Supreme Court accepted without discussion that the addition by Roosevelt and the "altered" boundaries by Eisenhower were valid. The monument was made part of the Glacier Bay National Park by an act of Congress in 1980 , but since the status of the land in 1959 (when Alaska was made a state) was the critical focus of its analysis, the National Park Act was not particularly relevant to that determination. While the Court did not discuss it further, the Eisenhower proclamation reduced the size of the Glacier Bay National Monument in three ways without any land swaps or additions to counter those reductions. More importantly, the grounds Eisenhower provided for that reduction are historically interesting and legally relevant.

In Proclamation 3089, issued March 31, 1955, Eisenhower reduced the size of Glacier Bay National Monument for three different reasons. ${ }^{208}$ One ground was that some lands "including several homesteads which were patented prior to the enlargement of the monument [by Roosevelt] are suitable for a limited type of agriculture use and are no longer necessary for the proper care and management of the object of scientific interest on the lands within the monument."209 Although Proclamation 3089 provides no further explanation of this exclusion, it is fair to read it as concluding that the original inclusion of this land was mistaken and, perhaps as important, that the lands were no longer necessary for the proper care of the objects of scientific interest in the monument.

The second reduction in the size of Glacier Bay National Monument was based squarely on Eisenhower's conclusion that such lands should have been included in Tongass National Forest instead of the national monument in 1939, when Roosevelt enlarged it, "and such lands are suitable for national-forest purposes." ${ }^{.10}$ Eisenhower determined that the earlier inclusion of these lands in the monument was in error, since their exclusion from the forest was "erroneous." $211 \mathrm{He}$ did not specifically declare that they were "no longer

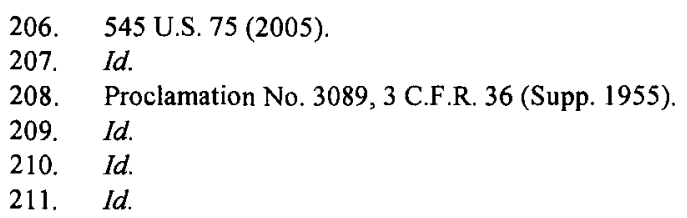


necessary" to the proper care of the objects of scientific interest in the Glacier Bay National Monument, but he must have concluded they were never necessary to be included or that the mistaken inclusion in 1939 was sufficient to exclude them in 1955 .

The third reduction (the first mentioned in the proclamation) was because certain lands are "now being used as an airfield for national-defense purposes and are no longer suitable for national-monument purposes."212 How land reserved in a national monument became a military airfield is not explained. In some respects, this may be the most interesting exclusion of all. Whether the earlier use of the land for an airfield was legal or not, Eisenhower asserted the authority to declare a higher government purpose for federal land that was part of a national monument and, by proclamation, to remove it from the national monument reservation. Note also that Eisenhower states that the airfield land was no longer suitable for inclusion in the national monument because it was an airfield, not that the land was otherwise unsuitable for inclusion in the monument. ${ }^{213}$ Would the same reasoning apply if it were not yet an airfield?

And while Eisenhower's total reductions in the size of Glacier Bay National Monument were not great relative to the monument's overall size, they were not trivial either. According to the National Park Service, the reductions total more than 4,100 acres of submerged land and 24,900 acres of other land. ${ }^{214}$ Most national monuments before 1955 did not even reach 29,000 acres. Moreover, some of President Eisenhower's other monument reductions constituted a larger proportion of the original size of the monument (e.g., Great Sand Dunes), and earlier presidential reductions were even greater, as discussed above.

Attempts to argue from its perambulatory purposes that the Antiquities Act does not authorize significant reductions are as conclusory as Cummings's analysis of the revocation issue. Reasoning from selective, broad protective purposes can always yield the desired result. ${ }^{215}$ We reach the opposite conclusion based on the text discussed above and consideration of all the Act's purposes, the original compromises the Act incorporated, and separation of powers principles.

Subsequent congressional land-management statutes do not change the Antiquities Act, but they cut sharply against the policy argument that the Act's use is necessary to promptly secure land that is otherwise prone to looting or harmful development. Indeed, these more recent laws provide the same or superior protection without undermining Congress' primary role in federal landuse decisions. Of special note, the Secretary of Interior now has statutory

\footnotetext{
212. Id. (emphasis added).

213. Id.

214. See THEODORE CATTON, LAND REBORN: A HISTORY OF ADMINISTRATION AND VISITOR USE IN GLACIER BAY NATIONAL PARK AND PRESERVE 146-47 (1995).

215. See SCALIA \& GARNER, supra note 115 , at 19 ("The purposivist . . . is free to climb up this latter of purposes and to 'fill in' or change the text according to the level of generality he has chosen.").
} 
authority to make emergency withdrawals of federal land with few limitations (and none relating to size), including land not under his department's jurisdiction, which expire no later than three years after they are withdrawn. ${ }^{216}$

After the authority granted in 1978, one can no longer truthfully justify the President's power to lock up land from reasonable public uses in perpetuity as an "emergency" measure to stop imminent harm, no matter how often this claim is made. Yet monument declarations do have one powerful, immediate effect: they stop or inhibit ongoing congressional debate and potential compromise over the land at issue. Congress has withdrawn many federal lands for heightened protection in specific laws that balance the interests of multiple stakeholders. Defenders of permanent, unalterable national monuments regularly implore the President to preempt or interfere with Congress' deliberations. Even so, they cannot reasonably argue that presidential authority under the act can work only in one direction and that the interest of the states and other citizens cannot be reconsidered.

If the President can revoke a prior monument altogether, there is no strong argument that he lacks the lesser power to significantly reduce the size of a monument. But even if the President lacks the power to revoke a monument, past practice includes proclamations that reduced some monuments to a fraction of their current size, such as President Taft's eighty-nine percent reduction of the Navajo Nation Monument. Moreover, we think the courts are more likely to uphold significant reductions if the President could credibly include in his determination that the original designation was inappropriately large relative to the object to be protected or has become so with changed circumstances.

It would bolster his position if the President includes any existing sitespecific justifications for reducing the particular monument's land reservation. For example, a President might issue a proclamation determining that limited resources prevent proper management of the largest national monuments, that other authority now exists for the excluded parcels to be regulated and managed (including perhaps a management plan for them), that changed technology or other changed circumstances allow a smaller area to be designated to protect the objects in question, or that other changed circumstances warrant such reductions.

The President's authority to significantly reduce the size of an existing monument would be less certain if the Supreme Court or an appellate court ruled that he lacked a general discretionary authority to revoke prior monument designations. But even then, we think the President would retain the authority, if not the duty, to reduce the size of existing monuments that were unreasonably large relative to the objects being preserved--or have become illegally large with changed circumstances. And such determinations should be entitled to the same or similar respect as the original reservations.

As with a complete revocation, someone would have to establish standing to sue to overturn a proclamation reducing the size of a monument, and that

216. 43 U.S.C. $\S \S 1714(\mathrm{e}), 1714(\mathrm{i})$ (2018). 
might be difficult in many cases. And even if standing is established, we think the challenger would have a significant burden to prove in order to prevail. If the challenge were based on a factual determination, such a challenger might have to prove an abuse of discretion to overcome the President's more recent determinations under the Act, or the courts might hold that some determinations under the Act are textually committed to the President's absolute discretion (absent corruption or a procedural failure) and not subject to judicial review. ${ }^{217}$

\section{Conclusion}

We have argued that the President retains a general discretionary power to revoke prior monument designations pursuant to the Antiquities Act. It is a general principle of government that the authority to execute a discretionary power includes the authority to reverse the exercise of that power. In the monuments context, this power is at its height when prior designations were made illegally or in contravention of the Act's mandate that designations be reasonable in size.

Moreover, the purpose of the Act supports the President in his ability to respond to new factual determinations or changes in circumstance that require modification of a monument's boundaries. The plain language of the Act, its legislative purpose, and the practice of past Presidents all support this conclusion. Most importantly, our conclusion is compelled by the constitutional principle of separation of powers. If Presidents choose not to protect their policies through Congress's bicameral process, they leave those policies vulnerable to their successors by constitutional design.

217. The D.C. Circuit Court of Appeals has held that at least some monument challenges are justiciable, even if the standard of review is unclear for some types of claims. See Tulare Cty. v. Bush, 306 F.3d 1138, 1142 (D.C. Cir. 2001) (rejecting one monument challenge as to its size but holding that the claim was justiciable). Certain claims should be easier for the judiciary to adjudicate. For example, the courts might rule whether the statutory conditions for a monument existed as a matter of law, including whether the President made a final determination, whether he did so by issuing a proclamation specified in the Act, and whether the monument was on "land . . . owned or controlled" by United States within the meaning of the Act. 
. 